
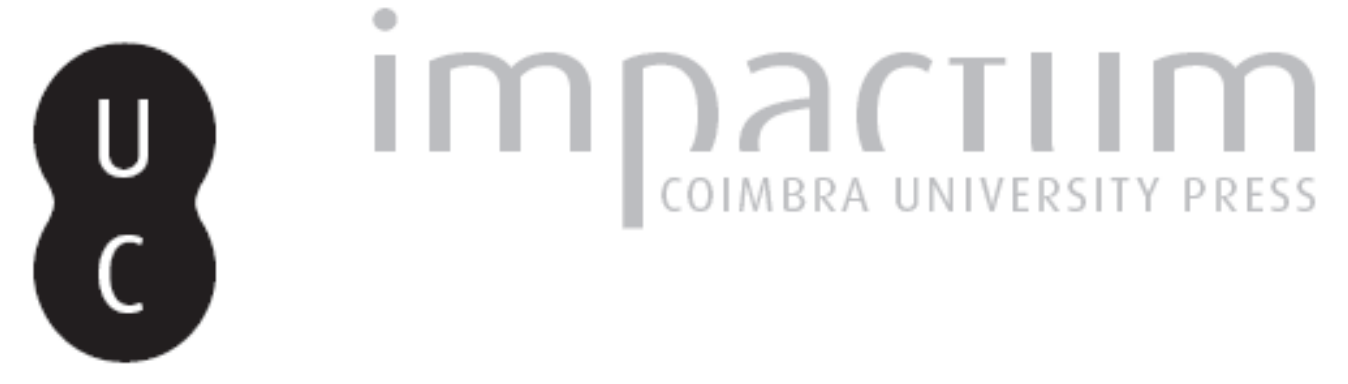

Onde a Terra se acaba e o mar começa: territórios de turismo e (in)sustentabilidade

Autor(es): $\quad$ Malta, Paula Alexandra; Eusébio, Celeste; Costa, Carlos

Publicado por: CEDOUA

URL persistente:

URI:http://hdl.handle.net/10316.2/8847

DOI:

http://dx.doi.org/10.14195/2182-2387_23_4

Accessed : $\quad$ 26-Apr-2023 14:11:32

A navegação consulta e descarregamento dos títulos inseridos nas Bibliotecas Digitais UC Digitalis, UC Pombalina e UC Impactum, pressupõem a aceitação plena e sem reservas dos Termos e Condições de Uso destas Bibliotecas Digitais, disponíveis em https://digitalis.uc.pt/pt-pt/termos.

Conforme exposto nos referidos Termos e Condições de Uso, o descarregamento de títulos de acesso restrito requer uma licença válida de autorização devendo o utilizador aceder ao(s) documento(s) a partir de um endereço de IP da instituição detentora da supramencionada licença.

Ao utilizador é apenas permitido o descarregamento para uso pessoal, pelo que o emprego do(s) título(s) descarregado(s) para outro fim, designadamente comercial, carece de autorização do respetivo autor ou editor da obra.

Na medida em que todas as obras da UC Digitalis se encontram protegidas pelo Código do Direito de Autor e Direitos Conexos e demais legislação aplicável, toda a cópia, parcial ou total, deste documento, nos casos em que é legalmente admitida, deverá conter ou fazer-se acompanhar por este aviso.

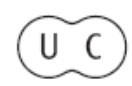


Doutrina

N.․․ 23 _Ano XII_1. 09

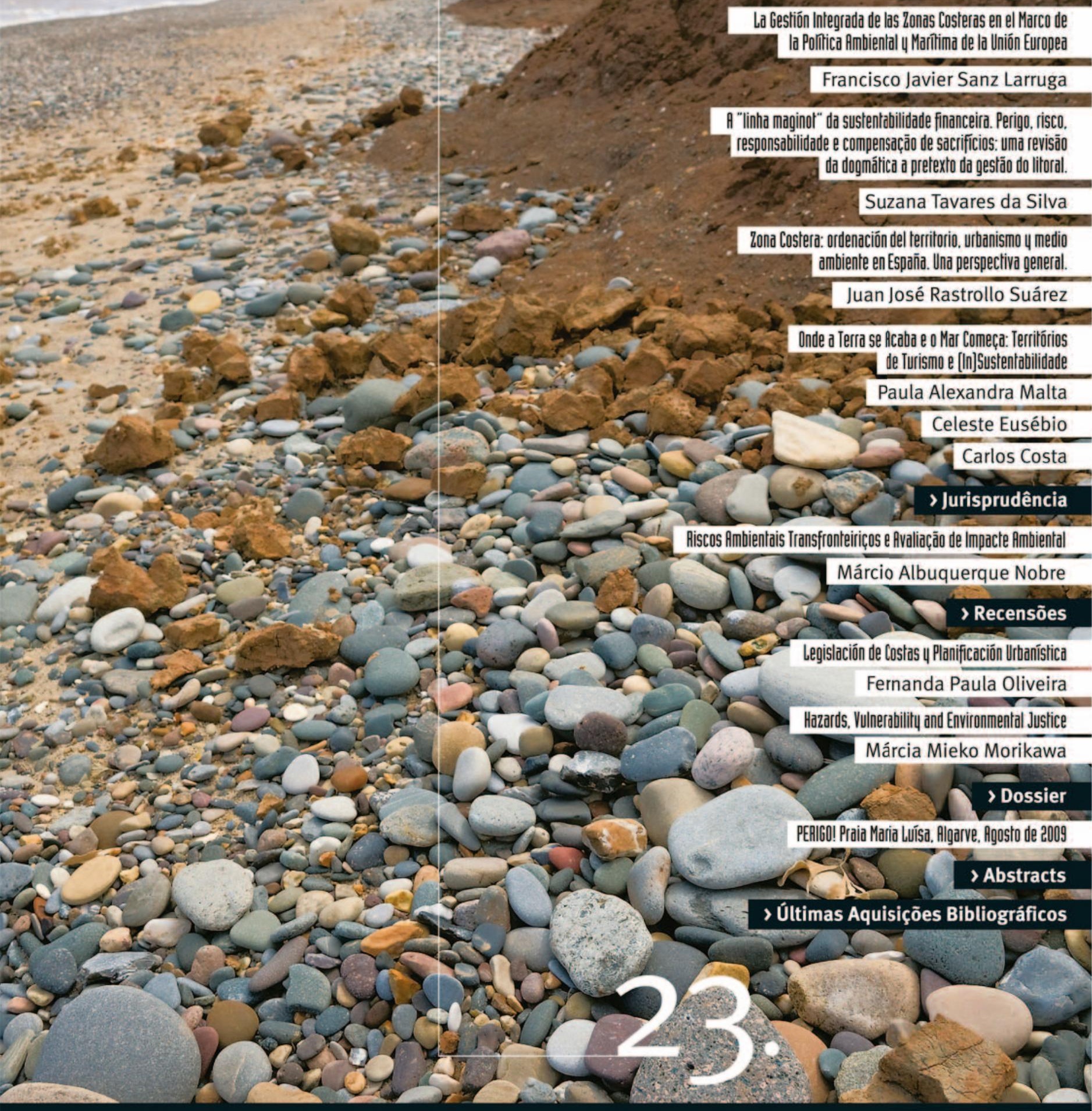

Revista do Centro de Estudos de Direito do Ordenamento, do Urbanismo e do Ambiente Urbanism, Territorial Order and Environment Studies Center Law Review 


\section{Onde a Terra se Acaba e o Mar Começa: Territórios de Turismo e (In)Sustentabilidade}

\section{Territórios do turismo em Portugal: (quase) todos os caminhos vão dar à costa \\ turismo em Portugal: (quase) todos os caminhos vão dar à costa}

\begin{abstract}
Litoralização e polarização metropolitana conformam os traços fundamentais da geografia do turismo em Portugal, decorrentes da especialização da oferta nacional no turismo costeiro (sol, praia e mar). Esta geografia da concentração reforça-se ainda mais porquanto o turismo se apropria de parcelas restritas da orla costeira, justamente aquelas que, pelas suas qualidades e valores excepcionais, são as mais sensíveis, obrigando à adopção de medidas de gestão integrada dos destinos costeiros em Portugal.
\end{abstract}

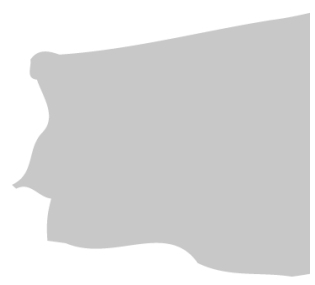

"Aberto largamente ao mar e este levando até muito longe a sua influência, o território português, nas suas feições fundamentais, revela uma simbiose permanente com o oceano contíguo"

Silva Telles (1932)

\subsection{Dinâmicas e grandezas do turismo em Portugal: a força dos números}

Se é verdade que, desde a sua génese, a história do turismo tem sido um relato de crescimento e diversificação, os dias que correm - de expansão exponencial das interacções com a consequente transformação das temporalidades e espacialidades - caracterizam-se, em resultado do volume, densidade, velocidade e universalidade dos fluxos - de pessoas, de capitais, de informações e de imagens e objectos (lembranças, artefactos, fotografias) que 0 turismo faz circular pelo mundo e das suas ressonâncias nas identidades e significados, ao colocarem crescentemente em contacto directo culturas distantes (Cochrane e Pain, 2000) -, por uma explosão das actividades, experiências, práticas e territórios legitimamente classificados como turísticos. 
Nas últimas seis décadas, maxime as que se seguem ao segundo conflito mundial e se estendem até aos anos 80 - arco temporal que alguns autores designam por fase fordista do turismo (Molina, 2003) -, a fileira turística conheceu um crescimento e diversificação contínuos, tornando-se numa das mais importantes actividades da economia mundial e, em simultâneo, numa das de mais rápido crescimento. A importância assumida pelo turismo na hierarquia da economia mundial tem sido unanimemente reconhecida, e, isto, seja qual for o indicador macroeconómico considerado para a aferição de tal grau de importância ${ }^{1}$. Eusébio (2006: 7) refere, a este propósito, que a "importância do turismo é reconhecida universalmente, tratando-se de um agente poderoso de alterações a nível económico, social, cultural e ambiental". Rodrigues (2006: 248) relembra que, segundo Nicolas (1994), "na fase fordista, o espaço turístico foi o que apresentou maior expansão no processo de globalização da economia", para depois fazer notar que este "notável crescimento continua significativo também na fase pós-fordista, do final do século XX até aos nossos dias".

Estas alterações têm concitado a atenção de vários autores, os quais se têm debruçado sobre a elucidação do papel do turismo nos processos de desenvolvimento. Dos argumentos que vêm sendo adiantados interessa aqui reter que a sustentação do papel relevante do turismo naqueles processos repousa nas incidências e ressonâncias geradas pela trama de efeitos - directos, indirectos e induzidos - de valoração positiva e de grande visibilidade não apenas nos tecidos sócio-económicos, mas também nas estruturas demográficas, nas esferas do património natural, da cultura, das mentalidades, da atenuação das disparidades espaciais, enfim, nas condições de estruturação dos territórios a diferentes escalas (Malta, 1996: 79).

É neste contexto que importa referenciar o percurso recente do turismo em Portugal, percurso que, para muitos, tem sido uma história de sucesso. Assumido, desde há muito, como vocação e oportunidade de desenvolvimento do País, o turismo foi elevado à posição de cluster estratégico prioritário nacional. No âmbito da Estratégia Nacional de Desenvolvimento Sustentável (ENDS 2015) e respectivo Plano de Implementação (PIENDS) ${ }^{2}$ - moldura

\footnotetext{
${ }^{1}$ Bastam dois indicadores - chegadas e receitas atribuídas ao turismo internacional - para tornar clara a verdadeira dimensão do turismo na economia mundial. Dados estatísticos da Organização Mundial do Turismo (OMT) demonstram que, em termos de grandes tendências e no cômputo de quase seis décadas (1950-2008), o turismo internacional cresceu 36 vezes no tocante às chegadas de turistas (visitante que permanece, pelo menos, uma noite num alojamento colectivo ou particular no lugar visitado): em termos absolutos, o número de chegadas de turistas internacionais em todo o mundo elevou-se de 25,3 milhões em 1950, para 277 milhões em 1960, 438 milhões em 1980, 684 milhões em 2000, totalizando o valor de 922 milhões no ano de 2008. A evolução das receitas do turismo internacional decalca de muito perto a tendência registada em termos de chegadas: em período homólogo, as receitas arrecadadas cresceram 450 vezes, passando de US $\$ 2,1$ biliões em 1950, para 944 biliões (642.000 milhões de euros) em 2008, estimando-se uma quebra, em termos reais (ajustada às flutuações cambiais e à inflação), de $6 \%$ no ano de 2009.

Outros elementos ajudam-nos a tornar ainda mais evidente tal grandeza: as exportações do turismo correspondem a $30 \%$ das exportações mundiais de serviços comerciais e a $6 \%$ das exportações de bens e serviços, situando-se em 4 - lugar, atrás dos combustíveis, produtos químicos e automóveis; a contribuição do turismo para o PIB mundial ronda os $5 \%$ e representa 6 a $7 \%$ do total de postos de trabalho (OMTa, 2010: 2). Saliente-se que esta magnitude se torna ainda mais expressiva se tivermos em consideração que nos valores ventilados não se encontram contabilizados os fluxos do turismo interno - o conceito de turismo interno reporta-se às actividades desenvolvidas pelos visitantes residentes num determinado país, no âmbito de uma deslocação no próprio país de residência - cujo peso relativo é, na maioria dos países desenvolvidos, muito superior ao dos fluxos turísticos internacionais e que, de acordo com estimativas da OMT, deverá ser 5 a 6 vezes superior. Anote-se, por exemplo, que em contextos de crise económica como aquele que vivemos, os consumidores tendem a viajar para destinos turísticos próximos dos seus locais de residência, pelo que o turismo interno revela maior resiliência. Em Portugal, à semelhança de outros países, o mercado interno traduz-se numa quota importante da procura total, contribuindo deste modo para compensar quebras da procura turística internacional, de que o ano de 2009 é exemplar ilustração.

${ }^{2}$ Aprovados pela Resolução de Conselho de Ministros n. ${ }^{0}$ 109/2007, de 20 de Agosto.
} 


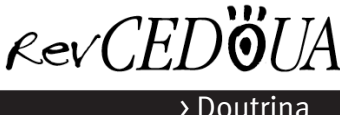

dos diversos instrumentos de planeamento e estratégias sectoriais no sentido de "tornar Portugal num dos países mais competitivos e atractivos da União Europeia, num quadro de elevado nível de desenvolvimento económico, social e ambiental e de responsabilidade social" - enfatiza-se a ascensão da cadeia de valor do macrocluster lazer-turismo. Neste enquadramento, o Plano Estratégico Nacional do Turismo (PENT 2015) considera tratar-se de uma "área decisiva para o desenvolvimento sustentável a nível ambiental, económico e social. 0 turismo é um sector estratégico prioritário para o País e deve dar um contributo significativo, nomeadamente através do aumento das receitas externas, para a cobertura do défice da nossa balança comercial e para o combate ao desemprego. Por outro lado, o turismo pode ter um contributo positivo para reforçar a imagem externa de Portugal e para a valorização do património cultural e natural do País. Contribui, assim, para a melhoria da qualidade de vida dos Portugueses e para a promoção da coesão territorial e identidade nacional enquanto recurso indutor de inúmeras actividades com ele relacionadas, contribuindo para o desenvolvimento sustentado em termos ambientais, económicos e sociais" ${ }^{3}$.

Não obstante as dificuldades em plasmar a verdadeira dimensão económica da actividade turística em Portugal, retenham-se alguns indicadores que permitem ilustrar esta magnitude. Desde o início da década de 70, o turismo tem registado elevadas taxas de crescimento: entre 1970 e 2008, as chegadas do turismo internacional em Portugal progrediram de 1.6 milhões para 12.3 milhões (Figura 1). Esta progressão foi acompanhada por correlativo acréscimo das receitas, as quais atingiram 6.9 mil milhões de euros em 2009, ao passo que em 1970 esse valor correspondia apenas a cerca de 1.8 milhões de euros (INE, 1971, 2010a). Estamos perante uma evolução que, ao reger-se por um ritmo de crescimento médio anual de $5,7 \%$, no período balizado entre 1970 e 2007, excede as taxas de crescimento médio anual das chegadas de turistas internacionais registadas a nível mundial ( $4,7 \%)$ e na Europa ( $4 \%$ ), em período homólogo.

\section{Figura 1 - Evolução das chegadas de turistas internacionais a Portugal (em milhões)}

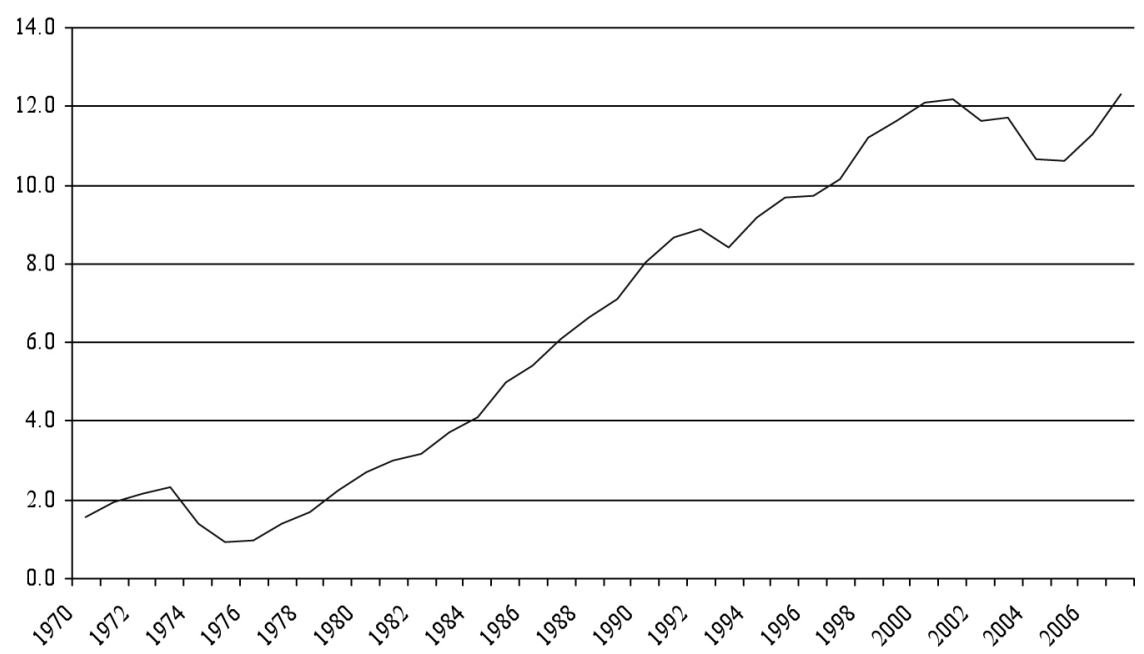

Fonte: elaborado a partir de dados da OMT (várias publicações)

\footnotetext{
${ }^{3}$ Resolução do Conselho de Ministros n. ${ }^{\circ}$ 53/2007, de 4 de Abril, que aprova os objectivos e principais linhas de desenvolvimento do Plano Estratégico Nacional de Turismo.
} 
Convirá frisar que, a partir de 2008 e em sintonia com a evolução do turismo à escala mundial, se regista uma desaceleração e menor performance do turismo em Portugal, associada às conjunturas de crise económica global e nacional (Quadro 1). Na verdade, para uma actividade acostumada a tendências de crescimento contínuo, os resultados globais apurados para 2009 revelam uma inversão destes ritmos, espelhada numa retracção da procura. Decaimento que, reflexo da quebra de confiança dos consumidores dos principais mercados emissores, se traduziu num abrandamento dos índices de propensão para viajar, imputáveis à conspiração negativa de vários factores. Factores que se alargam de um cenário de volatilidade e crise económicas mundiais - crise financeira, desemprego galopante, precariedade no emprego, congelamento de salários, restrições ao crédito, instabilidade nos preços do petróleo e das matérias-primas, bruscas flutuações cambiais, aumento dos deficits públicos... -, às incertezas da pandemia da Gripe A, já para não falar do agravamento que releva da contribuição das tensões políticas, das ameaças do terrorismo, das catástrofes ambientais e, muito importante, da própria mão da natureza ${ }^{4}$. Tamanhos obstáculos que levam o Secretário-Geral da OMT a afirmar, em momento recente, que "raras vezes na sua história, o turismo teve de enfrentar tantas dificuldades (...) transformando 2009 num dos mais duros anos para o turismo" (UNWTO, 2010b) ${ }^{5}$.

Esta evolução encontra-se, aliás, bem plasmada na Conta Satélite do Turismo, na qual se estima que a procura turística em Portugal, aferida pelo consumo turístico interior ${ }^{6}$, tenha totalizado 16,5 mil milhões de euros em 2009. Decalcando de muito perto a evolução do turismo à escala mundial, após dois anos consecutivos (2006 e 2007) de forte crescimento do consumo turístico e do valor acrescentado gerado pelo turismo (VAGT), em que se registaram níveis de crescimento nominal superiores aos da economia, torna-se inequívoco, a partir de 2008, um refreio deste desempenho (Quadro 1) (INE, 2009a, 2010a).

Tal não invalida, porém, a proeminência dos impactes positivos e bastante expressivos produzidos pelo consumo turístico na evolução da riqueza nacional: (i) para 2009, estima-se que o consumo turístico interior represente $10,1 \%$ do PIB da economia a preços de mercado; (ii) a relação entre o VAGT e o VAB da economia - indicador que permite avaliar o peso da riqueza gerada pelo turismo no conjunto da riqueza nacional - situou-se, em 2008, em $5 \%$;

\footnotetext{
${ }^{4}$ De que a ocorrência de eventos climáticos extremos ou as nuvens de cinzas expelidas pelo vulcão do glaciar Eyjafjallajokull, no sul da Islândia, são bons exemplos. As primeiras estimativas sobre os impactes do recente encerramento do espaço aéreo europeu, provocado pela actividade do vulcão Eyjafjallajokull situam "as perdas em aproximadamente 150 milhões de euros/dia para as companhias aéreas, números bem piores do que após os ataques terroristas de 11 de Setembro (...). Os agentes de viagens e outras empresas turísticas também vão sofrer elevados prejuízos, agravando as consequências da crise económica" (Pablo, 2010).

${ }^{5}$ Não obstante o mau desempenho, estes valores podem ser interpretados como sinais de resiliência comparativa dadas as condições particularmente difíceis da economia mundial, o que se torna muito clarividente quando comparado com estimativas de decréscimo de $12 \%$ das exportações totais.

${ }^{6} \mathrm{O}$ conceito estatístico de Consumo do Turismo Interior (CTI) corresponde ao "consumo efectuado por visitantes não residentes em Portugal (consumo do turismo receptor) e o consumo dos visitantes residentes que viajam unicamente no interior do país, mas em lugares distintos do seu ambiente habitual, assim como a componente de consumo interno efectuada pelos visitantes residentes no país, na sequência de uma viagem turística para o exterior do país (consumo do turismo interno), outras componentes do consumo turístico, tais como, o turismo por motivo de negócios, a valorização dos serviços de habitação das habitações secundárias por conta própria e as componentes não monetárias do consumo", conceito este que foi aprovado pelo Conselho Superior de Estatística desde 16-05-2008, de acordo com as recomendações da OMT (1995).
} 


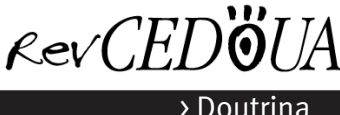

(iii) em 2006, o emprego nas actividades características do turismo ${ }^{7}$, ao elevar-se a 444 mil postos de trabalho ${ }^{8}$, mostra que a sua quota no emprego total na economia ascende a $8 \%$ (Quadro 1) (INE, 2009a, 2010a). De acordo com outras fontes, dados mais recentes publicados pelo WTTC (2010) adiantam que, em 2009, o turismo em Portugal contribuiu directamente com $5,7 \%$ do PIB e com $7,5 \%$ do emprego gerado. Se forem considerados os efeitos económicos totais desta fileira (directos, indirectos e induzidos) o efeito total do turismo ascende a $14,3 \%$ do PIB e $18,7 \%$ do emprego.

\section{Quadro 1 - Principais agregados da Conta Satélite do Turismo (2000-2009)}

\begin{tabular}{|c|c|c|c|c|c|c|c|c|c|c|}
\hline & 2000D & 2001D & 2002D & 2003D & 2004D & 2005D & 2006D & 2007P & 2008P & 2009E \\
\hline \multicolumn{11}{|l|}{ Consumo Turístico Interior (CTI) } \\
\hline Valor $\left(10^{6} \mathrm{C}\right)$ & 12308 & 12878 & 12725 & 12578 & 13450 & 13969 & 15150 & 17125 & 17327 & 16461 \\
\hline Taxa de variação nominal (\%) & & $4,6 \%$ & $-1,2 \%$ & $-1,2 \%$ & $6,9 \%$ & $3,9 \%$ & $8,5 \%$ & $13 \%$ & $1,2 \%$ & $-5 \%$ \\
\hline Peso do CTI no PIBpm (\%) & $10,1 \%$ & $10 \%$ & $9,4 \%$ & $9,1 \%$ & $9,3 \%$ & $9,4 \%$ & $9,7 \%$ & $10,5 \%$ & $10,4 \%$ & $10,1 \%$ \\
\hline \multicolumn{11}{|l|}{ Valor Acrescentado Gerado pelo Turismo (VAGT) } \\
\hline Valor $\left(10^{6} €\right)$ & 5054 & 5458 & 5443 & 5333 & 5787 & 5900 & 6378 & 7213 & 7309 & 6956 \\
\hline Taxa de variação nominal (\%) & & $8,5 \%$ & $-0,7 \%$ & $-2 \%$ & $8,5 \%$ & $2 \%$ & $8,1 \%$ & $13,1 \%$ & $1,3 \%$ & $-4,8 \%$ \\
\hline Taxa de variação nominal do VAB da Economia (\%) & & $5,9 \%$ & $4,4 \%$ & $2,3 \%$ & $4 \%$ & $2,4 \%$ & $3,7 \%$ & $5,1 \%$ & $2,9 \%$ & $-2 \%$ \\
\hline Peso do VAGT no VAB da Economia (\%) & $4,7 \%$ & $4,9 \%$ & $4,6 \%$ & $4,4 \%$ & $4,6 \%$ & $4,6 \%$ & $4,8 \%$ & $5,2 \%$ & $5,1 \%$ & n.d. \\
\hline \multicolumn{11}{|l|}{ Emprego nas actividades caracteristicas do turismo } \\
\hline № de postos de trabalho & 387865 & 398807 & 399329 & 409526 & 421660 & 432560 & 444373 & n.d. & n.d. & n.d. \\
\hline Taxa de variação (\%) & & $2,8 \%$ & $0,1 \%$ & $2,6 \%$ & $3 \%$ & $2,6 \%$ & $2,7 \%$ & n.d. & n.d. & n.d. \\
\hline Taxa de variação do emprego na Economia (\%) & & $1,3 \%$ & $7 \%$ & $-0,7 \%$ & $-0,2 \%$ & $-0,1 \%$ & $-0,70 \%$ & n.d. & n.d. & n.d. \\
\hline Peso do emprego do turismo no emprego da Econ. (\%) & $7,1 \%$ & $7,2 \%$ & $7,7 \%$ & $7,4 \%$ & $7,6 \%$ & $7,8 \%$ & $8 \%$ & n.d. & n.d. & n.d. \\
\hline
\end{tabular}

Notas: D - Dados definitivos; P - Dados preliminares; E - Dados estimados; n.d. - Dados não disponíveis

Fonte: elaborado a partir de dados do INE (2009a, 2010) e do Turismo de Portugal, IP (2008, 2009a, 2009b)

Se é certo que os indicadores económicos apresentados são tanto mais significativos se comparados com os valores homólogos registados às escalas europeia e mundial, colocando a descoberto que num "mercado altamente competitivo (...) e num contexto global de perda de quota de mercado da Europa, acentuam a competitividade demonstrada por Portugal enquanto um destino turístico" (ICEP, 2002), importa aqui deixar claro que o modelo de desenvolvimento turístico em vigor nas últimas décadas tem sido responsável pelo aparecimento de algumas deficiências estruturais conformadoras de ameaças à sua competitividade. Um dos problemas estruturais do turismo em Portugal prende-se, justamente, com o facto da cartografia por regiões das dinâmicas turísticas apontar para a ocorrência de situações e evoluções espacialmente diferenciadas e segundo velocidades distintas, cujo elemento caracterizador é dado pelo crivo litoral/interior.

\footnotetext{
${ }^{7} 0$ conceito estatístico de actividades características do turismo corresponde ao "conjunto de actividades cuja produção é identificada como sendo característica do Turismo, pela importância que assume na relação directa do fornecedor com o consumidor (visitante); algumas actividades são consideradas características devido à importância que nelas assume a produção associada aos visitantes, apesar de não lhes ser primordialmente dirigida, como é o caso de restauração e bebidas e os serviços de transporte de passageiros”, aprovado pelo Conselho Superior de Estatística desde 16-05-2008, de acordo com as recomendações da OMT (1995).

${ }^{8}$ Valor que corresponde a um incremento de 56500 postos de trabalho em relação a 2000 e traduz um crescimento médio anual de 2,3\%, enquanto, em período homólogo (2000-2006), o crescimento médio anual do emprego em Portugal foi de $0,2 \%$.
} 


\subsection{De territórios do vazio ${ }^{9}$ à invenção do litoral}

A litoralização da ocupação humana dos continentes intensifica-se em vastas áreas do globo - actualmente, a maior parte da população mundial ocupa zonas litorais, numa faixa que se estende até cerca de $100 \mathrm{~km}$ para o interior - e o turismo inscreve-se nestas tendências, sendo um dos principais responsáveis pela ocupação dos litorais. Portugal não foge a esta regra.

O turismo balnear constitui uma das práticas turísticas mais antigas e as orlas costeiras foram e continuam a ser um dos destinos turísticos mais procurados no mundo, na Europa (CE, 1999) e em Portugal. A procura de experiências de sol, praia e mar permanece a principal motivação de férias à escala mundial (OMT, 2009). Nos EUA, 90\% das despesas do turismo internacional concentra-se nos estados costeiros, sendo as praias os principais destinos turísticos (Houston, 1996). Segundo um estudo da Comissão Europeia (1998), o litoral é o destino turístico favorito de férias para $63 \%$ dos europeus; o mercado europeu de Sol e Mar é um mercado maduro que, em 2004, representava 69 milhões de viagens e que se estima que, em 2015, represente 80 milhões de viagens (Turismo de Portugal, 2007: 64). Em Portugal, as áreas costeiras são responsáveis pela vinda de cerca de $90 \%$ dos turistas estrangeiros que visitam o nosso País (UC Plano Tecnológico, 2005). Segundo dados mais recentes, recoIhidos no Verão de 2006, o produto Sol e Mar representa 41\% das motivações dos turistas estrangeiros em Portugal, valor que no Algarve sobe aos 88\% (Turismo de Portugal, 2007: 64).

Porém, nem sempre foi assim. Gostaríamos de sublinhar como ideia forte que falar hoje de ida à praia significa falar do ciclo mais recente destas práticas sociais que, pelos contornos materiais, formais e funcionais de que se reveste, permite que seja perspectivado em confronto com antigas práticas e, portanto, que seja considerado como uma criação histórica muito recente. Cavaco (2006: 300), ao questionar-se se alguns lugares terão vocação turística e outros não, conclui que "em turismo não há espaço para qualquer determinismo" e, secundando as ideias de Deprest (1997), insiste que "o lugar turístico é uma produção social, não eterna e que se inscreve numa história: o homem é capaz de criar, produzir, inovar o recurso turístico; foi a atracção do contacto directo com a praia que transformou os litorais 'territórios do vazio', marginais, em recursos turísticos; (...) a própria paisagem não é um objecto da natureza mas um produto social, com uma história aliás recente, que é a da sua percepção e da sua representação" (Cavaco, 2006: 301). "Lugar temido antes de ser terapêutico. Lugar deserto antes da moda dos banhos. Eis a praia ao longo do tempo. Ir para a praia nas horas mais quentes. Ficar na praia. Deleitar-se no contacto com a areia, a água e o sol. Há cem anos tudo isto seria considerado excentricidade em Portugal” (Ramos, 2009). Este despertar e construção do desejo colectivo de praia como espaço lúdico em que se valorizam os elementos quentes da natureza marítima é recente, remontando à segunda metade do século passado.

Classicamente, a praia e os lugares à beira mar, as orlas costeiras, eram percepcionados como territórios do vazio e o mar como símbolo do caos, do dilúvio e da punição divina (Corbin, 1989: 11-12), sendo esta tradição de repulsa e medo pela beira-mar alimentada pelos perigos reais ou fantasiosos do oceano. Delumeau (1978) classifica o mar como um dos mais comuns “topos de medo" do imaginário ocidental. Dias (2005: 9) dá, a este propósito, o tom

\footnotetext{
${ }^{9}$ Formulação emprestada da obra de Alain Corbin O território do vazio - a praia e o imaginário ocidental, cujo título condensa o essencial do discurso que aqui se expõe.
} 
da análise ao afirmar que "ao contrário do que, com frequência, é afirmado, a ocupação da generalidade das zonas costeiras foi sempre muito escassa": nas zonas costeiras, os estuários e lagunas costeiras foram, desde a pré-história, pólos de atracção para a ocupação humana, o mesmo não se verificando nos litorais arenosos oceânicos que, por serem inóspitos, eram evitados, sendo tardia a sua ocupação. Nas palavras sábias de Orlando Ribeiro (1987: 124), a costa portuguesa, "uma costa longa mas quase rectilínea, pobre em reentrâncias, diante de um oceano sem ilhas, oferece aos modos de vida litorais um domínio forçosamente limitado".

Na verdade, o desejo de praia - o desejo de estada à beira-mar, de banhos de mar, de contacto físico com a natureza marítima (Machado, 1996) - começou por ser edificado pela aristocracia europeia, balizando-se a inauguração destas idas a banhos de mar entre meados do século XVIII e princípios do século XIX (Corbin, 1989). A propósito das práticas sociais que, ao longo dos séculos XIX e XX, se expandiram no espaço de praia, aceita-se, com frequência, a tese defensora de uma construção social da praia assente numa cronologia bem distinta: num primeiro momento constitui-se a praia terapêutica frequentada por receita médica, à qual sucedeu a praia lúdica vocacionada para o prazer. Daqui decorrem duas notas importantes. Uma prende-se com a ideia de que o desejo de estar no espaço de praia surge associado ao comportamento das elites sociais e, portanto, como uma prática de distinção social. A elevação da praia à esfera da civilização, vale dizer, a sua percepção como uma prática civilizada releva de se tratar de um comportamento de distinção social: “a 'pré-civilização' é substituída pela invenção social de um comportamento 'civilizado': os banhos de mar, praticados pelas elites" (Machado, 1996: 44). A outra nota reporta-se ao facto de o processo social de inauguração da estada à beira-mar, deixando para trás o seu estatuto de território do vazio, começou por indicação médica: os banhos de mar, no seu duplo carácter higiénico e terapêutico, tomavam-se como remédio, não por prazer e, deste modo, "sob a égide do discurso médico, o desejo da praia vai-se converter na necessidade de efectuar uma terapia do corpo e da alma" (Machado, 1996: 61). Estas práticas talassoterapêuticas persistiram até meados do século XX (Dias, 2005: 10).

Em Portugal, no entanto, a procura e antropização da sua orla costeira pelo turismo parecem não ter trilhado este caminho. Machado (1996) argumenta que, nesta primeira fase de apropriação da praia como prática social da aristocracia portuguesa, houve uma clara secundarização das suas finalidades terapêuticas. Não obstante, entre finais do século XVIII e inícios do século XIX, a estada na praia ser recomendada para a cura de numerosas doenças através de banhos de mar, o verdadeiro objectivo do remédio era fruir de uma vida social intensa à beira-mar, um pretexto para divertimento. É, pois, manifesta a dominância das intenções lúdicas sobre as terapêuticas e foi só com a chegada da burguesia que se edificou a praia terapêutica ${ }^{11}$ em

\footnotetext{
${ }^{10}$ Na exposição exímia de Dias (2005: 9) “estes ambientes, com particular relevância para os litorais arenosos, caracterizam-se por serem agrestes (com grandes amplitudes térmicas diárias, forte insolação, muito ventosos, com ar carregado de salsugem, quase sem vegetação e, com frequência, sem água doce facilmente acessível), parcos em recursos básicos (pois que a areia da praia e dos campos dunares inviabiliza a agricultura, e o acesso aos recursos pesqueiros é dificultado pela rebentação das ondas), e apresentarem elevada vulnerabilidade no que se refere a riscos naturais (grandes temporais, tsunamis, etc.). A ocupação humana destes ambientes inóspitos tornava-se ainda mais difícil devido aos riscos inerentes aos conflitos armados, em que adquirem particular acuidade os relacionados com o corso e a pirataria”. Registe-se que na costa portuguesa, o corso e a pirataria perduraram até ao século XVIII. ${ }^{11} \mathrm{Na}$ praia da Nazaré, por exemplo, eram prescritos cinco banhos diários para as maleitas dos ouvidos (Freitas, 2007). Retenha-se, também, o seguinte excerto do capítulo intitulado "Reconstituição dos temperamentos e dos caracteres pelo banho frio", da obra de Ramalho Ortigão (1876: 265) As praias de Portugal: guia do banhista e do viajante: "venho simplesmente pedir às mães que dêem banhos (no mar) aos seus filhos: Peço-o para felicidade deles, para a sua regeneração física e moral, para a preservação das suas enfermidades, para a alegria do seu espírito, para a firmeza da sua vontade”.
} 
Portugal (Machado, 1996), para num outro momento posterior se dar, então, lugar à construção da praia como território do lazer e de veraneio e ao alargamento gradual da base social ${ }^{12}$ e democratização da sua procura. A representação social da praia como lugar vocacionado para o prazer e como prática democratizada e progressivamente massificada é coisa moderna que data tão só de meados do século XX.

Num litoral rarefeito de ocupação humana, com largas extensões quase desertas ou pontilhado por pequenas povoações de pescadores, o crescente interesse pela praia levou à valorização progressiva de retalhos cada vez mais extensos da costa portuguesa, em particular dos litorais arenosos oceânicos, com "edificações várias para apoio à novel actividade do turismo balnear, sejam casas para alojamento de famílias, sejam hotéis para o visitante ocasional, sejam clubes e casinos para ocupação de tempos livres" (Dias, 2005: 12). É no quadro deste processo de expansão dos lugares de vilegiatura marítima - que, nos finais do século XIX e inícios do século XX, faz surgir várias estâncias balneares -, que ocorre o nascimento, em 1914, da primeira estância turística em Portugal, construída de raiz, o Estoril, fundada sobre a combinação dos produtos praia-termas-jogo. Por volta dos anos 30 do século passado, além das praias do Estoril, Cascais e Paço de Arcos, o aparecimento de estâncias balneares situa-se, de modo predominante, no Norte e Centro do País, (pela concatenação de factores demográficos, económicos e de acessibilidade): Póvoa do Varzim, Espinho e Figueira da Foz começam a encher-se de gente, centripetando uma clientela que outrora ia a termas, a ponto de se dar uma inversão na hierarquia das preferências dos portugueses, com crescente favoritismo da praia em detrimento das estâncias termais.

Encontramos aqui o início da corrida ao litoral e sua ocupação sistemática. Freitas (2007) assinala que várias vilas e cidades do litoral português são o produto da expansão da vilegiatura marítima; entre as mais antigas, contam-se as de Vila do Conde, Póvoa de Varzim, Espinho, Nazaré, Figueira da Foz, Ericeira e Cascais; já no século XX, podem mencionar-se Vila Nova de Milfontes, Praia da Rocha, Quarteira, Albufeira e Monte Gordo. Foi a partir de finais da década de 50 que se deu o grande surto de crescimento do turismo em Portugal, cuja imagem dominante é, até aos dias de hoje, a de praias apinhadas, de portugueses e estrangeiros, na qual a região do Algarve é cabeça de cartaz: "o boom turístico gerado a partir dos países europeus mais prósperos mas carentes de sol, obriga os operadores internacionais à busca insana de novas estâncias balneares ao longo da bacia mediterrânea. Nos finais de 50, a corrida atinge o Algarve, que irrompe, pletórico, da letargia que o isolamento geográfico o condicionara” (Pina, 1987: 223).

Da sujeição do turismo a um progressivo processo de industrialização ${ }^{13}$ e internacionalização resulta a emergência e modelização do turismo de massas. A massificação das práticas turísticas - entendendo massificação no sentido de participação social alargada e

\footnotetext{
${ }^{12}$ Alargamento, é certo, mas com regras e a regra era a cada um a sua praia: Figueira da Foz, Espinho e Póvoa de Varzim eram praias cosmopolitas, frequentadas por banhistas de todas as regiões e até de Espanha; Leça era a praia preferida da colónia inglesa do Porto; Vila do Conde, Granja e Cascais eram as eleitas da aristocracia; Furadouro, Vieira de Leiria e Lagos procuradas por gentes das localidades mais próximas; na Apúlia, Costa Nova, S. Jacinto, Torreira, Mira, Pedrogão e Baleal reuniam-se famílias conhecidas (Guia de Portugal, 1924-27, citado por Freitas, 2007: 114). ${ }^{13} \mathrm{O}$ itálico é para não perder nunca de vista que o turismo, enquanto actividade económica, não é uma indústria mas uma composição de serviços, e portanto a incorrecção, anotada pela própria OMT, da expressão indústria turística, resultante da tradução abusiva do termo inglês tourism industry (Dewailly e Flament, 2000: 12). A sua utilização neste contexto enfatiza, justamente, a imagem das hordas douradas de Turner e Ash (1975), de migração massiva duma grande tribo de bárbaros; carrega, igualmente, a ideia de práticas estandardizadas e organizadas industrialmente, e o significado de massificação associado ao sistema de produção industrial fordista e corolário da sociedade de consumo de massa. Sublinhe-se que, mesmo na literatura anglo-saxónica, a noção de turismo
} 
sua expansão - não releva, em exclusivo, da conquista por amplos sectores da população de direitos sociais relacionados com o aumento dos tempos livres, apesar de tal constituir uma condição necessária e fundamental; resulta, isso sim, da confluência de um conjunto amplo de forças motrizes. Aliás, o turismo de massas, entendido como um processo de packaging em larga escala de serviços padronizados, é o resultado lógico das circunstâncias sociais, económicas e políticas do pós-guerra e reporta-se às características preponderantes de que se revestiu o turismo internacional durante os anos 60, 70 e 80 do século XX.

A massificação do turismo em Portugal emula as macro-tendências firmadas à escala global, desde meados do século XX, de procura vertiginosa dos destinos balneares marítimos. Tendências às quais Portugal, pela sua posição geográfica e com uma extensíssima zona costeira, em comparação com a sua superfície geográfica - uma fachada continental longamente aberta para o mar (que com os seus $848 \mathrm{~km}$, corresponde a $41 \%$ dos contornos do País e a $1 \mathrm{~km}$ de costa por cada $100 \mathrm{~km} 2$ ), a que se juntam os territórios das regiões autónomas da Madeira e dos Açores (Orlando Ribeiro, 1987: 123; Brito, 1994: 11) e uma das mais extensas zonas económicas exclusivas da União Europeia - não poderia escapar. Tem sido no litoral, na qualidade das suas condições naturais (físicas e climáticas) para o acolhimento de veraneantes (Brito, 1994: 314), que Portugal foi encontrar o caminho para o seu desenvolvimento turístico. Para além da extensão da sua costa, Portugal possui outras condições para Sol e Mar: é o país da Europa com maior número de horas de sol por ano; elevada qualidade das praias (254 praias com bandeira azul, em 2010); diversidade de recursos e atractivos para o produto Sol e Mar - "a costa oeste do país tem praias com qualidade para desportos como o surf e o kitesurf, o Algarve tem características mediterrânicas e uma temperatura da água elevada (face às praias atlânticas), e o Porto Santo é um destino de "clima tropical", situado apenas a 3 horas de voo do centro da Europa" (Turismo de Portugal, 2007: 64). Também o turismo comprova a veracidade da afirmação de Lautensach, no ido ano de 1932, sobre quão "intimas são as relações de Portugal (...) com as regiões confinantes do Oceano Atlântico, a oeste e a sul” (Lautensach, 1987).

Neste padrão de intensa apropriação sazonal dos litorais é possível identificar várias tipologias de destinos costeiros. Uma prende-se com a diferenciação entre destinos onde o turismo se desenvolveu na presença de estruturas preexistentes (com frequência de dimensões reduzidas, de que são exemplo pequenas comunidades piscatórias) para se transformarem em verdadeiras aglomerações onde a actividade turística passa a ser dominante, por contraponto às estâncias balneares construídas de raiz nas frentes de mar, as quais se podem definir como sistemas territoriais de produção e distribuição de bens e serviços turísticos (CE, 1999: 21). Outra tipologia distingue praias de férias - para onde os veraneantes se deslocam de armas e bagagens - de praias localizadas próximo de centros urbanos importantes e que são objecto de intensa procura nos fins-de-semana (Dias, 2005).

como uma indústria tem gerado forte controvérsia. A génese desta expressão remonta, segundo Leiper (1995, citado por Higgins-Desbiolles, 2006), aos anos 60, época em que as indústrias eram vistas como motores do crescimento económico. Face à forte pregnância da ideologia industrial, sobre a qual se erigiu uma visão depreciativa do turismo e das actividades terciárias em geral, Davidson (1994) faz notar que a expressão indústria turística permitiu a credibilização da fileira, desvinculando-a dos conceitos de divertimento, recreio, lazer, carácter improdutivo e estruturalmente dependente e, portanto, a sua popularização prende-se com uma imagem económica para fins políticos, de forma a assegurar financiamento público e políticas fiscais favoráveis (Leiper, 1995). Para Higgins-Desbiolles (2006), estes argumentos não perdem peso no actual quadro de neoliberalismo, em que o discurso industrialista do turismo continua a ser utilizado para assegurar apoio e recursos que de outro modo se tornariam inacessíveis. 
Em suma, “muitos trechos costeiros, que ao longo de toda a História quase não tinham sido ocupados, ficaram sobreocupados em poucas décadas" (Dias, 2005: 14). O litoral português, que permanecera território do vazio até ao despertar do desejo colectivo de praia, viu as suas paisagens serem transformadas de modo radical às mãos do turismo. Para que conste assinale-se que, a partir dos anos 50, neste adensar do tecido turístico no litoral português, a vilegiatura estival assume uma forma e dimensão novas: "a forma é a ida para as praias do sul (...), a dimensão passa, em poucos anos a medir-se em dezenas de milhões de pessoas" (Brito, 2003: 708). As bem vincadas assimetrias que caracterizavam as décadas anteriores entre os litorais a norte do Tejo e o do Algarve, inverteram-se, com rapidez, transformando a costa sul do país na principal região turística portuguesa, posição consolidada até hoje. Começam, pois, a desenhar-se os traços fundamentais da geografia do turismo em Portugal, que Brito (1994: 314) sintetiza, de modo exemplar, ao escrever "em Portugal, os territórios turísticos por excelência são as praias, principalmente as do Algarve”.

\section{Um olhar sobre a geografia do turismo em Portugal}

\subsection{Agenda analítica, operacionalização de conceitos e plano metodológico}

Perante o cenário descrito, o que nos move não é fazer uma geografia turística do litoral português mas tão-só a identificação e caracterização dos padrões locativos da actividade turística em Portugal, centrando a agenda investigativa na clivagem litoral/interior, de forma a avançar no sentido duma reflexão sobre as implicações de tais configurações geográficas nas estratégias de desenvolvimento turístico emergentes e, deste modo, confirmar ou infirmar a veracidade do seguinte articulado de hipóteses:

$\mathrm{H}_{1}$ - Existe uma forte dicotomia entre litoral e interior em termos de desenvolvimento da actividade turística;

H2 - Existem diferenças consideráveis relativamente à incidência espacial da actividade turística ao longo da orla costeira;

$\mathrm{H}_{3}$ - A forte litoralização e polarização metropolitanas da actividade turística em Portugal têm fortes implicações no desenvolvimento sustentável desta actividade.

Antes de avançarmos, convirá estabilizar os contornos e conteúdos de alguns conceitos, nomeadamente, os conceitos de turismo e de orla costeira aqui sufragados e explicitar algumas das opções do plano metodológico traçado.

Turismo é, na verdade, um conceito de difícil abordagem e operacionalização pela amplitude e heterogeneidade de aspectos que recobre. Para Martin e Mason (1987: 112), uma fórmula elementar para dar conta do que se entende por turismo diria que é um termo que carrega uma enorme variedade de actividades, cuja única ligação reside no facto de os sujeitos envolvidos se encontrarem a viajar. Não espanta, deste modo, que existam inúmeros ensaios de conceptualização. Das incontáveis propostas de definição do que vimos designando por turismo, o que se afigura, neste caso decisivo é a sua operacionalização. Convoca-se, assim, uma definição de natureza eminentemente operativa que considera as "actividades realizadas pelos visitantes, durante as suas viagens e estadas, em lugares distintos do seu ambiente habitual, por um período de tempo consecutivo inferior a 12 meses, com fins de lazer, negócios ou outros motivos não relacionados com o exercício de uma actividade remunerada no local visitado"; nesta definição "excluem-se as viagens cujo motivo principal consiste na prestação de serviços a uma entidade residente no país (local) visitado, envolvendo o pagamento da respectiva remuneração (decorrente de um contrato de trabalho ou uma relação empregado/ 


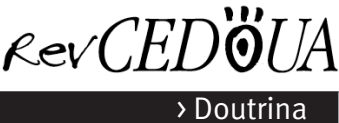

empregador). Se este trabalho e a respectiva remuneração não estão directamente relacionados com o motivo principal da viagem, então a viagem insere-se no âmbito do turismo", conforme proposta da OMT (2005) e adoptada pela Decisão (CE) n.ำ 1999/34/CE, de o9 de Dezembro.

São também inúmeros os problemas associados aos exercícios de conceptualização quanto ao que se entende por litoral, zona litoral, região litoral, costa, zona costeira, faixa costeira, orla costeira, região costeira... A primeira dificuldade decorre, desde logo, da frequente utilização indiferenciada destes termos ${ }^{14}$. A segunda releva da inexistência de uma definição consensual: aliás, "se há algum consenso no que respeita à complexidade da zona costeira (dos processos actuantes e das respostas dos sistemas), à sua sensibilidade, ao seu dinamismo, à sua importância económica e ecológica, à ocorrência de conflitos entre utilização e equilíbrio natural, à pressão aí exercida, à necessidade de promover o seu uso sustentável, já o mesmo não se passa em relação ao estabelecimento dos seus limites físicos, sendo estes muito variáveis nos diversos conceitos e documentos legais existentes" (MAOTDR, 2007: 35). Os problemas adensam-se, ainda mais, na medida em que não são poucas as vozes que se erguem em defesa de uma definição pouco rígida e de limites flexíveis que se ajuste ao carácter dinâmico dos territórios costeiros (Comissão Europeia, 1999a; MAOTDR, 2007); a dinâmica destes territórios de dimensões variáveis na interface entre a Terra e o Oceano são quase sempre incompatíveis "com a rigidez imposta por limites, qualquer que seja a ordem de grandeza destes. 0 conceito pode abranger maiores ou menores extensões terrestres ou marítimas" (MAOTDR, 2007: 35). Nesta prodigalidade de definições, a operacionalização do conceito de litoral aqui perfilhada é, face aos objectivos e ordem de grandeza da escala de análise adoptada, aquela que considera o litoral como o conjunto das NUTs III com orla costeira, operacionalização, aliás, já adoptada por outros autores (Ferreira, 1997) porquanto se é "frequente identificar-se o litoral com os concelhos que têm orla costeira ou com as NUTs III, (...) são grandes as contradições que resultam desse facto: a malha daqueles é muito mais fina no norte do que no sul, enviesando a representação de muitas variáveis; a largura da faixa é, neste caso, inversamente proporcional à área de penetração da influência marítima. A escolha dos limites da NUT III uniformiza mais essa largura" (Ferreira, 1997: 58).

Quanto às opções metodológicas referentes à utilização da capacidade de alojamento dos estabelecimentos hoteleiros como variável que traduz a oferta turística e das dormidas efectuadas neste tipo de unidades de alojamento para representar a procura, retenha-se que as razões que estiveram na base da ventilação destas variáveis prendem-se com a existência de informação estatística disponível desagregada à escala sub-regional e com o facto de os estabelecimentos hoteleiros ocuparem, em termos quantitativos, uma posição de liderança no quadro da oferta de alojamento turístico licenciado ${ }^{15}$.

\footnotetext{
${ }^{14}$ Também neste artigo, as diferentes designações serão utilizadas de forma indistinta posto que os objectivos e a escala de análise estabelecidos não obrigam a tal diferenciação. Não se esquece, todavia, que, em conformidade com as orientações estabelecidas no Código de Conduta Europeu para as Zonas Costeiras, os vários termos correspondem a uma hierarquia espacial, pelo que, em Portugal, no documento Bases para a estratégia de gestão integrada da zona costeira nacional (MAOTDR, 2007: 36), se consideram as seguintes distinções: litoral é um termo geral que descreve porções do território influenciadas directa ou indirectamente pela proximidade do mar; zona costeira designa a porção do território influenciada directa ou indirectamente em termos biofísicos pelo mar (ondas, marés, brisas, biota ou salinidade) que, para o lado da terra se estende por uma largura de ordem quilométrica e para o lado do mar até ao limite da plataforma continental; orla costeira corresponde a porções do território onde o mar exerce directamente a sua acção, coadjuvado pela acção eólica, e que se estende para o lado da terra por uma largura de centenas de metros e do lado do mar até à batimétrica dos 30 metros; linha de costa designa a fronteira entre a terra e o mar, materializada pela intercepção do nível médio do mar com a zona terrestre.

${ }^{15} \mathrm{Em}$ 2009, a capacidade de alojamento dos estabelecimentos hoteleiros foi de 273.804 camas, ao passo que a das colónias de férias e a das pousadas da juventude não ultrapassava 6.138 e 4.661 camas, respectivamente (INE, 2010). Por sua vez, em 2008, a capacidade de alojamento do Turismo no Espaço Rural (TER) não supera as 11.692 camas (INE, 2009).
} 
Recorrendo a indicadores que permitem avaliar a localização espacial da actividade turística, procedeu-se a tal avaliação utilizando as NUTs III como unidade territorial de referência. A avaliação do desenvolvimento turístico das zonas costeiras de Portugal e a comparação deste desenvolvimento com as restantes regiões turísticas do País assenta na categorização das NUTs III localizadas no continente em dois grupos: NUTs III com orla costeira e restantes NUTs III. Esta análise foi suportada por indicadores turísticos - capacidade de alojamento dos estabelecimentos hoteleiros e dormidas nos estabelecimentos hoteleiros - e por medidas de localização - densidade turística (DT), taxa de função turística (TFT), índice de saturação turística (IST) e intensidade de utilização (IU) -, cuja formalização se encontra sistematizada no Quadro 2. Estas medidas de localização, ao relacionarem duas ou mais variáveis cuja distribuição regional se põe em confronto, fornecem uma imagem mais correcta do padrão espacial da actividade turística em Portugal.

\section{Quadro 2 - Formalização das medidas de localização}

\begin{tabular}{|c|c|c|c|}
\hline \multirow{2}{*}{$\begin{array}{l}\text { Oferta } \\
\text { turística }\end{array}$} & Densidade turística & $D T_{i}=\frac{C A_{i}}{S_{i}}$ & \multirow{2}{*}{$\begin{array}{l}C A_{i}-\text { Capacidade de alojamento dos } \\
\text { estabelecimentos hoteleiros na região } i \\
S_{i}-\text { área total em Km² na região } i \\
P R_{i}-\text { População residente na região } i\end{array}$} \\
\hline & $\begin{array}{l}\text { Taxa de função } \\
\text { turística }\end{array}$ & $T F T_{i}=\frac{C A_{i}}{P R_{i}} \times 100$ & \\
\hline \multirow{2}{*}{$\begin{array}{l}\text { Procura } \\
\text { turística }\end{array}$} & $\begin{array}{c}\text { Índice de saturação } \\
\text { turística }\end{array}$ & $I S T_{i}=\frac{D_{i}}{P R_{i}}$ & \multirow{2}{*}{$\begin{array}{l}D_{i} \text {-Dormidas totais nos estabelecimentos } \\
\text { hoteleiros na região } i \\
S_{i} \text { - área total em } \mathrm{Km}^{2} \text { na região } i \\
P R_{i}-\text { População residente na região } i\end{array}$} \\
\hline & $\begin{array}{l}\text { Intensidade de } \\
\text { utilização }\end{array}$ & $I U_{i}=\frac{D_{i}}{S_{i}}$ & \\
\hline
\end{tabular}

A avaliação das diferenças em termos de concentração espacial da actividade turística, por mercados emissores de turistas, arrancou da utilização do número de dormidas efectuado nos estabelecimentos hoteleiros de acordo com o país de residência (residentes em Portugal e residentes no estrangeiro), para avançar no sentido da determinação da taxa de captação de turistas, indicador que relaciona as dormidas efectuadas por cada mercado em determinada região com as dormidas imputáveis a esse mercado em Portugal.

\subsection{Um padrão de forte litoralização e polarização metropolitanas}

A cartografia da oferta e da procura turísticas em Portugal configura o desenho de um persistente mosaico de contrastes regionais e locais (Sirgado, 1993), configurações geográficas retratadas, de modo inequívoco, no Quadro 3 e Figuras 2 e 3. Avaliando quer o peso da capacidade de alojamento no quadro da oferta nacional quer o peso das dormidas das oito NUTS III cujos valores são inferiores a 0,5\%, todas correspondem a áreas do interior do País (Figuras 2 e 3). 


\section{$\operatorname{Rer} C E D$ öUA

Quadro 3 - Capacidade de alojamento, superfície e população residente em Portugal, por regiões (2008)

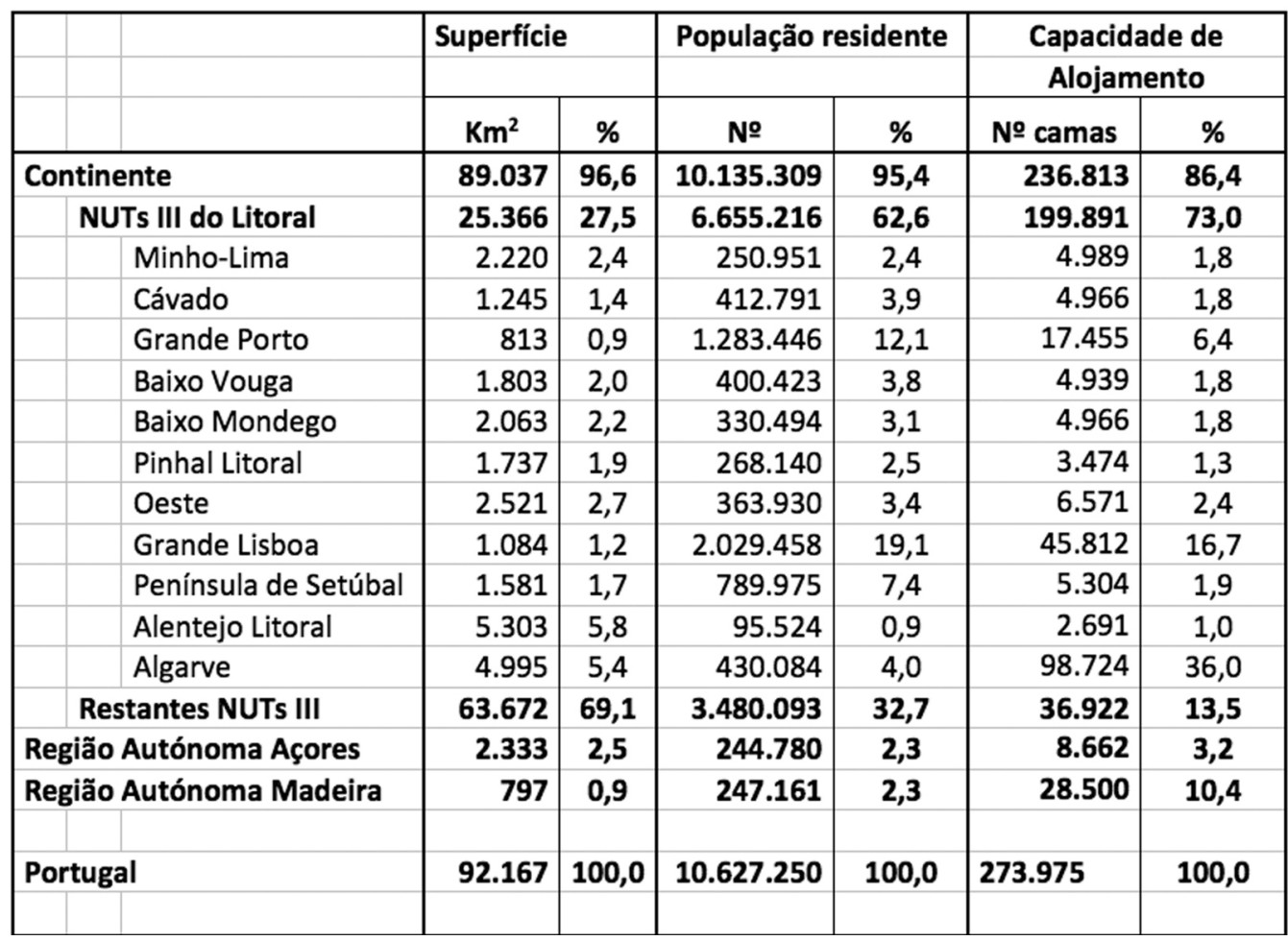

Fonte: elaborado com base em dados do INE (várias publicações).

Mais ainda, os contrastes entre regiões com elevada capacidade de alojamento turístico e regiões onde esta capacidade é quase nula acentuam-se à medida que existe um deslocamento no sentido litoral/interior. Em geral, verifica-se que as regiões do interior dispõem de uma capacidade de alojamento turístico insuficiente e de baixas taxas de captação de turistas, embora sejam detentoras de relevantes potencialidades turísticas, nomeadamente de recursos naturais, culturais e paisagísticos de grande valor, que importa qualificar e promover.

Em 2008, das 273.975 camas existentes nos estabelecimentos hoteleiros, cerca de $86 \%$ encontram-se localizadas nas NUTs III do litoral e nas Regiões Autónomas, as quais representam apenas cerca $30 \%$ da área total de Portugal e $67 \%$ da população. 0 Algarve, a Região da Grande Lisboa e a Região Autónoma da Madeira concentram 63,1\% da capacidade de alojamento total mas a sua superfície é uma parcela que se queda por $7,5 \%$, do território nacional. Nas posições mais fragilizadas posicionam-se as NUTS III localizadas no interior do país que ocupam cerca de $2 / 3$ da superfície do país mas contribuem, escassamente, com cerca de $13,5 \%$ da capacidade de alojamento dos estabelecimentos hoteleiros de Portugal (Quadro 3). 
Figura 2 - Distribuição da capacidade de alojamento dos estabelecimentos hoteleiros por NUTS III (2008)

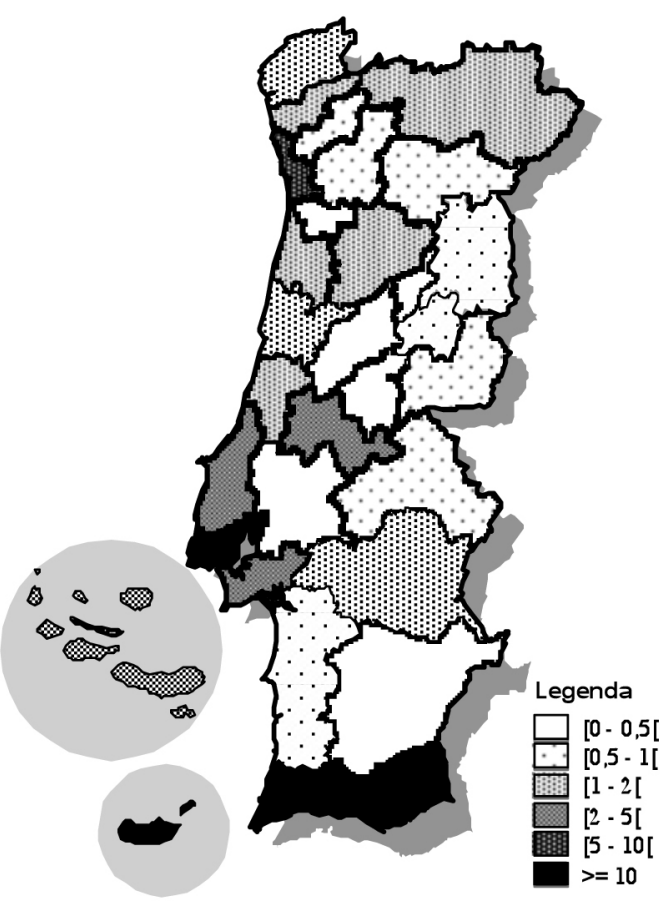

Figura 3 - Distribuição das dormidas nos estabelecimentos hoteleiros por NUTS III (2008)
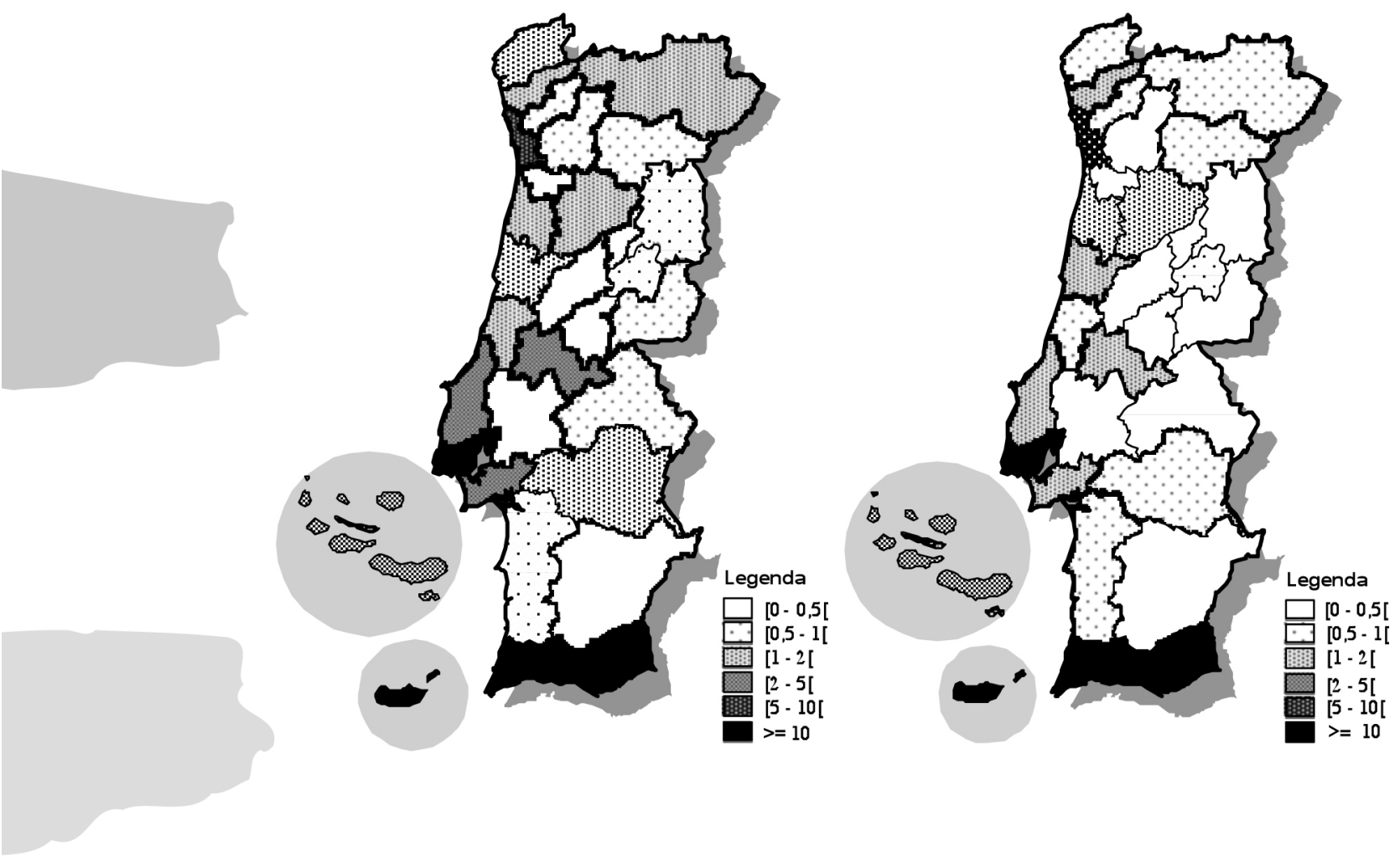

Fonte: elaborado com base em dados do INE (várias publicações)

Da perspectiva da procura, esta leitura não só encontra plena adesão como sai reforçada, não se detectando nem novas nem substanciais modificações nos padrões locativos traçados. A avaliação da distribuição espacial das dormidas totais nos estabelecimentos hoteleiros consagra o Algarve como a região responsável pela quota mais elevada (36,4\% das dormidas totais). Se às dormidas realizadas no Algarve se adicionarem as ocorrências contabilizadas na Madeira e na Grande Lisboa, apura-se que estas três regiões, embora representem menos de 1/10 da superfície do território nacional, polarizam 71,8\% da procura, afirmando-se como as principais áreas de captação turística do país (Quadro 4 e Figura 3). Convirá esclarecer que este modelo de fracturação dicotómica litoral/interior do espaço turístico nacional conforma uma leitura simplificada e redutora, porquanto esconde marcadas diferenciações inter-locais, aliás já identificadas por Sirgado (1993). Das onze NUTs III do continente localizadas no litoral, a capacidade de captação de oito destas NUTs estaca no valor de $10 \%$ das dormidas totais nos estabelecimentos hoteleiros. 


\section{$\operatorname{RerCED\varrho ̋UA~}$

Quadro 4 - Distribuição espacial da procura turística em Portugal (2008)

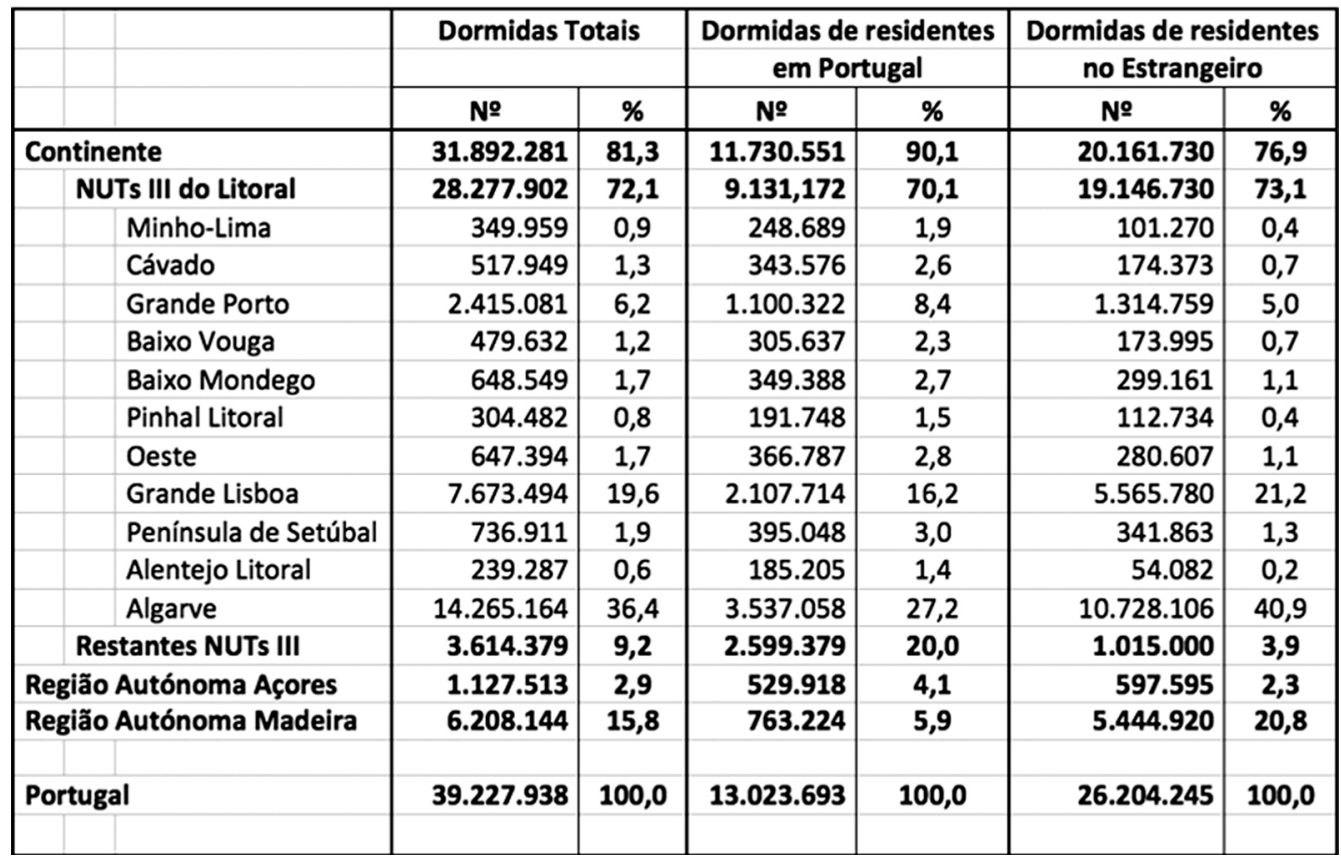

Fonte: elaborado com base em dados do INE (várias publicações)

Verificada a forte diferenciação do espaço regional em matéria de incidência das dinâmicas turísticas, questiona-se, agora, se a heterogeneidade dos padrões de distribuição geográfica da procura turística releva do tipo de mercado que procura o destino Portugal. Daqui resulta que a segmentação dos mercados emissores se traduza na partição do mercado total (dormidas totais) em mercado nacional (dormidas de residentes em Portugal) e mercado estrangeiro (dormidas de residentes no estrangeiro).

A avaliação dos padrões de distribuição espacial dos mercados emissores permite concluir que as dormidas efectuadas por estrangeiros revelam um padrão muito mais concentrado do que o das dormidas realizadas por hóspedes residentes em Portugal (Quadro 4). Para atestar este facto, sublinhe-se a sobre-valorização da região algarvia, por parte dos mercados estrangeiros, face aos restantes espaços regionais, ao drenar mais de $2 / 5$ do total de dormidas de estrangeiros em Portugal (40,9\%); situação contrastante com o valor da polarização exercida sobre o mercado nacional, o qual não ultrapassa os $27,2 \%$. Por seu turno, as NUTs III que não fazem parte da orla costeira de Portugal revelam-se muito pouco atractivas para o mercado estrangeiro, o que se infere das baixas taxas de captação (3,9\% das dormidas totais); reúnem, contudo, uma preferência acrescida no seio do mercado nacional, porquanto captam cerca de $1 / 5$ das dormidas deste mercado (Quadro 4). Estes resultados evidenciam que o mercado estrangeiro gera padrões geográficos muito mais concentrados do que o mercado nacional, facto preocupante na medida em que o mercado estrangeiro é responsável por $63 \%$ das dormidas totais efectuadas nos estabelecimentos hoteleiros. 
Padrão homólogo ao suportado pela análise dos indicadores turísticos já descritos (capacidade de alojamento e dormidas) se desenha quando se procede à determinação da taxa de função turística (Quadro 5).

\section{Quadro 5 - Distribuição espacial da actividade turística em Portugal - medidas de localização (2008)}

\begin{tabular}{|c|c|c|c|c|c|c|}
\hline & & & $\begin{array}{c}\text { Densidade } \\
\text { Turística (DT) }\end{array}$ & $\begin{array}{l}\text { Taxa de Função } \\
\text { Turística (TFT) }\end{array}$ & $\begin{array}{c}\text { Índice de } \\
\text { Saturação } \\
\text { Turística (IST) }\end{array}$ & $\begin{array}{l}\text { Intensidade } \\
\text { de Utilização } \\
\text { (IU) }\end{array}$ \\
\hline \multicolumn{3}{|c|}{\begin{tabular}{l|l} 
Continente & \\
\end{tabular}} & 2,66 & 2,34 & 3,15 & 358 \\
\hline & \multicolumn{2}{|c|}{ NUTs III do Litoral } & 7,88 & 3,00 & 4,25 & 1.115 \\
\hline & & Minho-Lima & 2,25 & 1,99 & 1,39 & 158 \\
\hline & & Cávado & 3,99 & 1,20 & 1,25 & 416 \\
\hline & & Grande Porto & 21,48 & 1,36 & 1,88 & 2.972 \\
\hline & & Baixo Vouga & 2,74 & 1,23 & 1,20 & 266 \\
\hline & & Baixo Mondego & 2,41 & 1,50 & 1,96 & 314 \\
\hline & & Pinhal Litoral & 2,00 & 1,30 & 1,14 & 175 \\
\hline & & Oeste & 2,61 & 1,81 & 1,78 & 257 \\
\hline & & Grande Lisboa & 42,26 & 2,26 & 3,78 & 7.079 \\
\hline & & Península de Setúbal & 3,35 & 0,67 & 0,93 & 466 \\
\hline & & Alentejo Litoral & 0,51 & 2,82 & 2,50 & 45 \\
\hline & & Algarve & 19,76 & 22,95 & 33,17 & 2.856 \\
\hline & $\mathbf{R e}$ & ntes NUTs III & 0,58 & 1,06 & 1,04 & 57 \\
\hline \multicolumn{3}{|c|}{ Região Autónoma dos Açores } & 3,71 & 3,54 & 4,61 & 483 \\
\hline \multicolumn{3}{|c|}{ Região Autónoma da Madeira } & 35,76 & 11,53 & 25,12 & 7.789 \\
\hline & & & & & & \\
\hline Portugal & & & 2,97 & 2,58 & 3,69 & 426 \\
\hline
\end{tabular}

Fonte: Elaborado com base em dados do INE (várias publicações)

Este indicador coloca a descoberto que, em Portugal, a capacidade de alojamento existente nos estabelecimentos hoteleiros se restringe a $2,58 \%$ da população residente. Contudo, no Algarve tal valor ultrapassa os $22 \%$ e na Madeira aproxima-se dos $12 \%$. Estas duas regiões de forte incidência turística destacam-se num cenário onde os demais contextos regionais, principalmente os localizados no interior do país, apresentam taxas que rondam a unidade. Os valores da taxa de função turística das NUTs III localizadas no litoral e das restantes NUTs III do continente constituem outros elementos que vincam as dissemelhanças fundamentais das dinâmicas turísticas no território nacional. No Litoral habita $63 \%$ da população residente em Portugal e a capacidade de alojamento instalada permite alojar $3 \%$ dos residentes. Por sua vez, as NUTs III do interior, nas quais reside $33 \%$ dos portugueses, dispõem de uma capacidade de alojamento que só permite alojar cerca de 1\% da população (Quadro 5 e Figura 5). 
Figura 4 - Densidade Turística por NUTS III (2008)

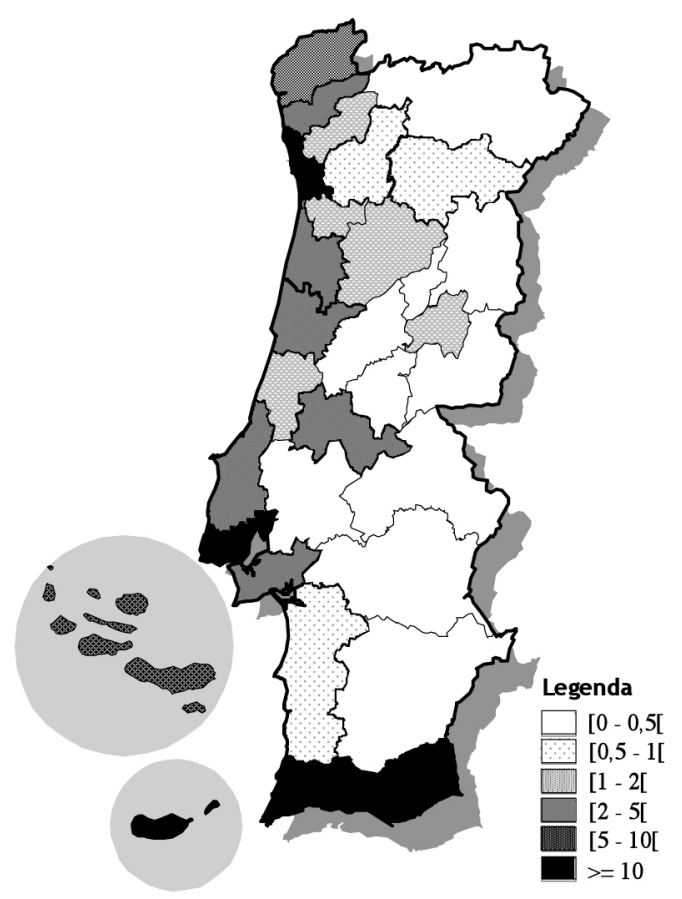

Figura 5 - Taxa de Função Turística por NUTS III (2008)

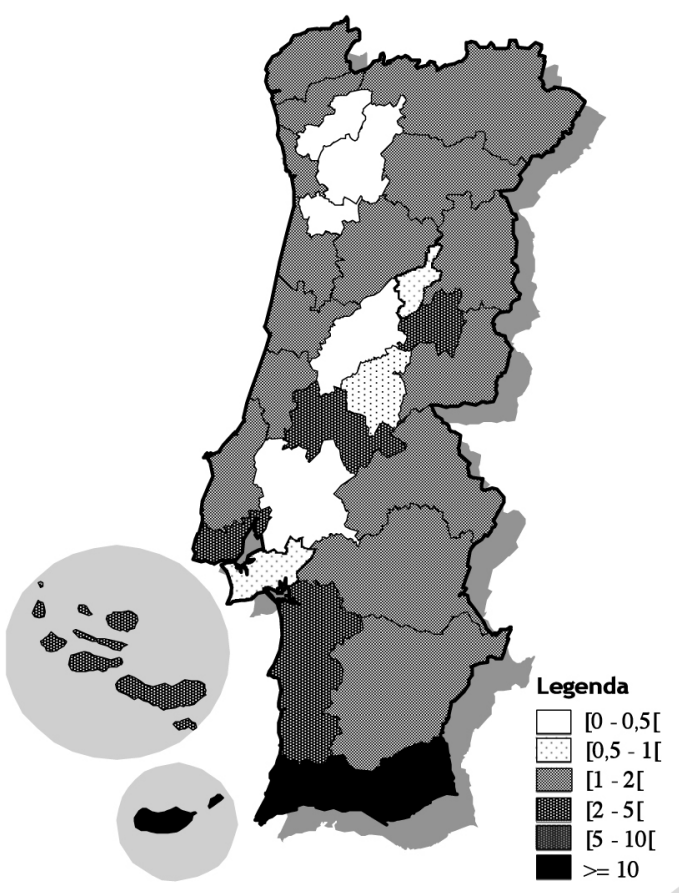

Fonte: elaborado com base em dados do INE (várias publicações)

A ventilação de uma outra medida estatística importante - a densidade turística - , ao anular os efeitos decorrentes da dimensão física de cada circunscrição administrativa, introduz elementos de variação na hierarquização do posicionamento das várias regiões (Quadro 5 e Figura 4). Ultrapassando largamente o valor médio nacional balizado em 2,97 camas $/ \mathrm{km} 2$, a Região da Grande Lisboa assume, agora, a posição de destacada liderança com valores que rondam 42 camas/km2, secundada pela Região Autónoma da Madeira, com 36 camas/Km2. Nesta relação, as NUTs III localizadas no interior são as regiões mais perdedoras, não chegando a possuir $1 \mathrm{cama} / \mathrm{km} 2$, ao contrário das regiões do litoral que, em média, são detentoras de 8 camas/km2 (Quadro 4 e Figura 4).

Em linha com os resultados obtidos a montante, mudanças nas dimensões de análise conduzem à intensificação das assimetrias espaciais reveladas, o que significa dizer, à inscrição de consistentes diferenciações inter-regionais, pautadas por vigorosos processos de litoralização e polarização metropolitanas (Quadro 5 e Figuras 6 e 7). 


\section{RerCEDöUA}

Figura 6 - Índice de Saturação
Turística por NUTS III (2008)

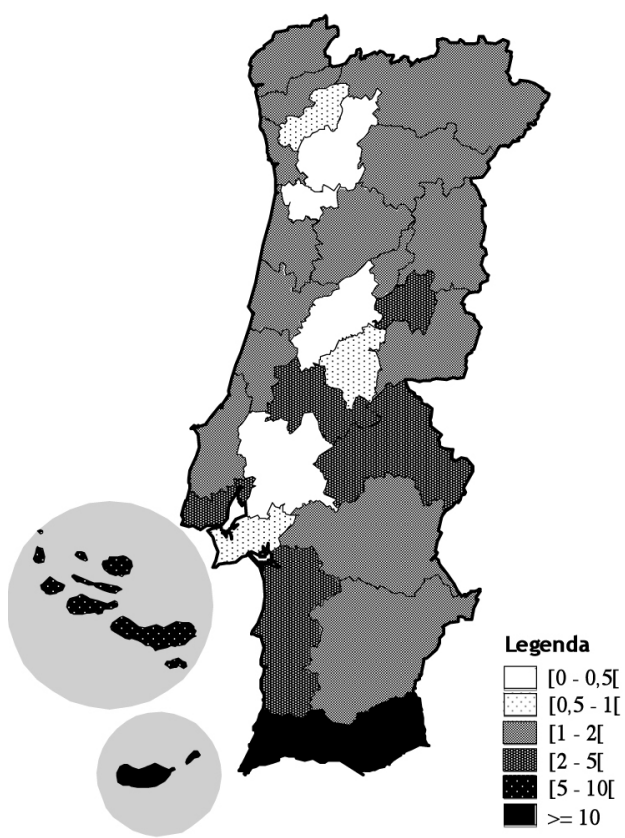

Figura 7 - Intensidade de Utilização Turística por NUTS III (2008)

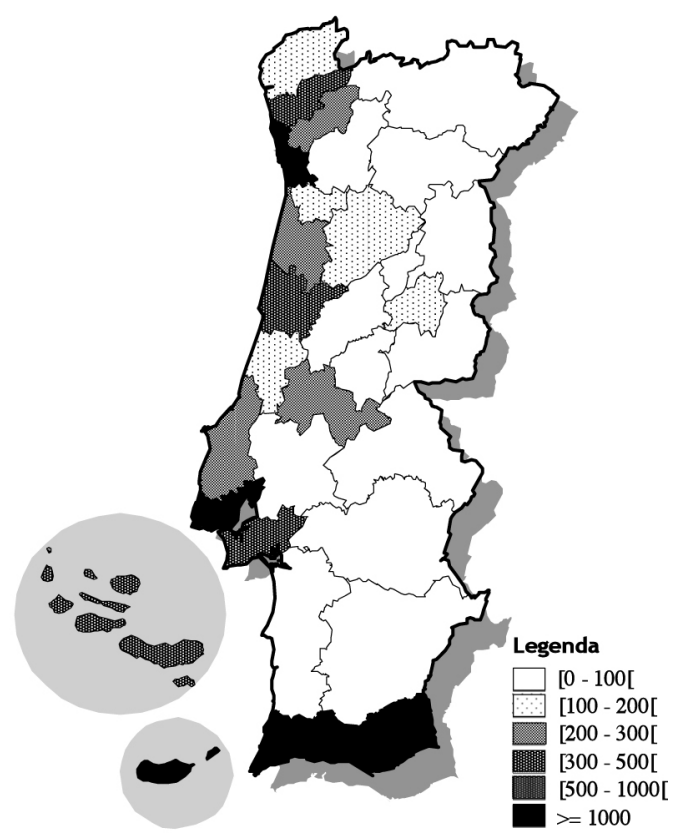

Fonte: elaborado com base em dados do INE (várias publicações)

A dissecação de indicadores como o índice de saturação turística e a intensidade de utilização demonstram, com muita nitidez, que o mosaico de contrastes revelado pelos indicadores associados à oferta turística é bem mais vincado quando se olha para o turismo na perspectiva da procura. Se, em Portugal, no ano de 2008, ocorreram 3,69 dormidas/ habitante, o Algarve sobressai com 23 dormidas/habitante. As NUTs III localizadas no litoral do país exibem um índice de saturação turística superior à média nacional, em contraste com os valores muito inferiores à média nacional apurados para as NUTs do interior.

Estes resultados são reforçados quando se avalia a distribuição das dormidas em estabelecimentos hoteleiros por $\mathrm{km}^{2}$ (intensidade de utilização): mais uma vez, emerge como dimensão caracterizadora relevante o facto de as regiões do interior do país captarem, em média, 55 dormidas nos estabelecimentos hoteleiros $/ \mathrm{Km}^{2}$, enquanto nas regiões do litoral este valor ascende a 1.115 dormidas $/ \mathrm{Km}^{2}$. Numa abordagem mais fina, confirma-se a subrepresentação e periferização de extensas parcelas do território nacional e que litoralização e polarização metropolitanas constituem dois traços fundadores da geografia do turismo em Portugal. A Região Autónoma da Madeira lidera o ranking das regiões com níveis de intensidade turística mais elevados ( 7.789 dormidas $/ \mathrm{km}^{2}$ ), seguindo-se a região da Grande Lisboa (7.079 dormidas $/ \mathrm{km}^{2}$ ). Nos antípodas, encontram-se regiões como o Pinhal Interior Sul com valores que não ultrapassam 11 dormidas $/ \mathrm{km}^{2}$ e o Baixo Alentejo com 21 dormidas/ $\mathrm{km}^{2}$ (Quadro 5 e Figuras 6 e 7). 


\section{$\operatorname{RerCED\varrho ̈̈UA~}$}

\section{Pensar a orla costeira, o turismo e a sua gestão ou a história da galinha dos ovos de ouro}

\subsection{Torcendo o território: o estrago do El Dorado}

Das leituras a montante efectuadas sobre alguns contornos da geografia do turismo em Portugal, emerge, como dimensão caracterizadora relevante do posicionamento alcançado por Portugal no turismo mundial, a confirmação da veracidade da hipótese de uma apropriação e utilização para fins turísticos fortemente contrastada do território nacional, traduzida numa forte oposição entre litoral e interior.

Esta cartografia, que reflecte o cenário prevalecente nas últimas décadas, demonstra a existência de um padrão de cerrada concentração espacial, em que litoralização e polarização metropolitana conformam os traços fundamentais da vincada segmentação regional do espaço turístico nacional. Processos de litoralização e polarização metropolitana plasmados na clara demarcação e reforço das três regiões turísticas tradicionais - Algarve, Lisboa e Madeira - consequente da concretização da trajectória de especialização da oferta nacional no produto sol e mar e para onde tendem continuar a confluir, numa espiral centrípeta, os factores de desenvolvimento (turistas, empresas, capitais, acessibilidades...).

O progressivo acentuar das fracturas, no sentido do reforço concentracionário nas regiões mais desenvolvidas turisticamente e da periferização das regiões afastadas destes núcleos motrizes, penalizando os territórios do interior, onde tais dinâmicas continuam a pautar-se por desenvolvimentos muito incipientes, tem-se baseado na "progressiva especialização da oferta turística nacional num produto assente no sol e praia, resultando portanto, em termos práticos, no crescimento mais rápido das regiões que melhor se adaptavam a este modelo de desenvolvimento turístico" (Henriques, 1993: 57), modelo que trouxe a consolidação do Algarve como destino internacional de sol, praia e mar. Esta geografia da concentração das dinâmicas turísticas vai ainda mais longe porquanto no seio das próprias regiões, o turismo apropria-se de pequenas porções do território. Mais, sobrepõe-se e reforça os tradicionais desequilíbrios regionais do país revelados em tantas outras esferas, quer no que diz respeito à litoralização da vida do País, quer no tocante à centralidade da área metropolitana de Lisboa.

Porém, a cerrada polarização geográfica descrita conforma uma das principais ameaças ao desenvolvimento do turismo nacional, na medida em que na base desta polarização se encontra o apelo pelo litoral. Já no Livro Branco do Turismo (MCT, 1991) se considerava que o principal desequilíbrio estrutural reside na dependência de um produto, o sol e praia, o qual está na origem da escolha por parte da generalidade dos turistas que seleccionam Portugal como destino; o segundo desequilíbrio mais relevante radica, precisamente, nas questões da concentração geográfica do turismo.

As orlas costeiras, enquanto áreas de transição entre a terra e o mar, constituem territórios de elevada complexidade sistémica, complexidade da qual decorrem o elevado dinamismo, biodiversidade, variabilidade e muitas potencialidades que as caracterizam (valores ecológico, paisagístico e económico), mas também a extrema sensibilidade e vulnerabilidade dos seus ecossistemas. Ao mesmo tempo, não apenas em Portugal mas em todo o mundo, as áreas costeiras estão sob violentas pressões antrópicas, em escala e intensidade, causadas pela rápida urbanização e acréscimo populacional e em que o turismo assume posição de destacada liderança. Mais, sendo o uso turístico apenas um dos muitos usos dos territórios costeiros - e mesmo no que diz respeito aos usos turísticos podem surgir incompatibilidades entre diferentes tipos de turismo -, estes conformam-se como áreas de severos conflitos de 
interesses, não apenas entre as pressões que procedem da colisão dos diferentes usos mas entre estas e as questões da sustentabilidade ambiental. É por este motivo que a gestão das zonas costeiras é, quase por definição, uma gestão de conflitos (Dias, 2005; Freitas, 2007); mais, ainda, porque o turismo se apropria de áreas restritas do litoral, justamente aquelas que, pelas suas qualidades e valores excepcionais, são as mais sensíveis.

E, todavia, o turismo é o principal interessado em assegurar os valores ecológicos e paisagísticos das zonas costeiras, vale dizer, em terra e no mar, uma vez que o seu estrago, pelos efeitos danosos ou mesmo irreparáveis que produz, arrasta a perda de atractividade e de competitividade, e não poucas vezes, a sua própria ruína. Apuros que se ampliam no quadro do actual avolumar da procura turística por lugares de excepcional qualidade ambiental.

Contudo, o que esta apetência e pressão sem regras significaram para a orla costeira está à vista. Face aos benefícios económicos directos do turismo e à incapacidade de resposta e inexperiência em matéria de intervenção voluntária estadual, e perante a pujança e celeridade das novas dinâmicas territoriais colocadas em marcha pelo turismo, quase tudo foi permitido no processo de conversão do litoral num local apetecível e muito procurado: artificialização progressiva do solo com o acréscimo das áreas e volumes das construções, aparecimento de avenidas marginais e paredões longitudinais, edificações o mais próximo possível do mar, tantas vezes em cima de dunas e arribas, deficits hídricos decorrentes da sobre-exploração de aquíferos e carências de água potável, deficiências dos sistemas de saneamento básico, declínio (ou mesmo desaparecimento) de actividades tradicionais, sub e sobre dimensionamento (nas épocas alta e baixa) das estruturas de apoio (Dias, 2005: 23; Freitas, 2007). Tomemos como ilustração a região objecto de mais intensa pressão turística e transformação da paisagem em Portugal: em "Agosto, o Algarve começou a ser invadido por multidões, que as infra-estruturas regionais não conseguiam aguentar: faltava a água e gasolina, os engarrafamentos multiplicavam-se, os restaurantes estavam cheios e a qualidade baixava enquanto os preços disparavam. Por outro lado, a implantação estreitamente litoral e, em larga parte, extra-urbana da nova actividade turística, desequilibrou a pacata organização regional. Enquanto o Barrocal e a Serra tendem a esvaziar-se cada vez mais, o Litoral cobre-se de uma urbanização bastante caótica (...). 0 Algarve está ainda longe de ter encontrado um novo equilíbrio e bases seguras para o seu desenvolvimento" (Daveau, 1995: 121).

Indispensáveis ao estabelecimento do horizonte de compreensão desta situação são, também, as dificuldades que para Portugal, enquanto destino turístico balnear tradicional, relevam do agravamento da concorrência, pela incorporação de novos destinos de sol e praia noutras latitudes e longitudes. Longos trechos da nossa orla costeira são agora destinos turísticos maduros, alguns dos quais saturados que, vencidos pelos novos destinos, se vêem "na contingência de baixar os preços, sendo ocupadas por um turismo de massas frequentemente com baixo poder económico" (Dias, 2005: 23).

De outra banda, tentar um esclarecimento desta questão implica, também, assumir, como ponto de partida, a emergência de uma consciência ambiental que em turismo se traduz, entre outras tendências, pelo mito do retorno à natureza ou, dito de outro modo, a recuperação do natural como território de experiência turística, não propriamente no sentido de retorno à vida selvagem ou do mito do paraíso perdido (Cavaco, 1998: 76), mas consequente da centralidade e consolidação da causa verde na sociedade do risco de Beck (1992) e da procura do real como expressão da modernidade tardia (Munt, 1994; Bell e Lyall, 2002). Por outro lado, desoculta-se a ideia de que os turistas da modernidade tardia procuram consumir qualquer coisa que se encontra em vias de extinção, como se essa ameaça constituísse uma 


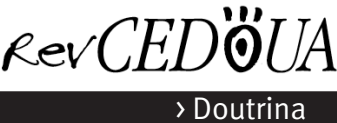

fonte de atraç̧ão: "as paisagens ditas naturais ou em vias de extinção estão a transformar-se em verdadeiros santuários. Visitar o que ainda não desapareceu e que faz parte da história da Terra e do ser humano é um filão em crescimento" (Cravidão, 2006: 277).

Estas mutações apresentam, por seu turno, conexões estreitas e particulares com a preponderância firmada pelos valores estéticos nos processos de selecção dos destinos turísticos. Motivações que estão na base de práticas absolutamente «incompatíveis com a degradação e artificialização do litoral. E, no entanto, é por este tipo de turismo, normalmente procurado pelos segmentos médio e elevado, que compensa competir, até porque, mesmo em termos económicos, é, de longe, o mais compensador" (Dias, 1995: 24).

O generalíssimo quadro acabado de traçar explica a actual voracidade predadora pela orla costeira do Alentejo, que sendo uma das mais bem preservadas da Europa e comportando longos trechos em áreas classificadas, possui um elevado índice de atractividade turística e, simultaneamente, um desafio para um modelo de desenvolvimento turístico sustentável.

Outro aspecto central que aqui importa inscrever é o que procede das consequências das alterações climáticas para os destinos costeiros. Se todos os destinos turísticos são sensíveis ao clima, a sensibilidade do turismo balnear em relação a condições climáticas favoráveis é elevadíssima, assumindo particular significado nos processos de tomada de decisão do turista e na experiência de viagem, na medida em que afectam os índices de conforto, de segurança e de satisfação dos turistas e, portanto, as suas decisões de viagem (UNEP e WMO, 2008).

A velocidade e os potenciais efeitos das alterações climáticas no turismo e o reconhecimento da urgente necessidade de desenvolver e implementar estratégias de adaptação e de prevenção, bem como de mitigação dos impactes ambientais do turismo nesta matéria, têm suscitado a atenção de vários autores (Agnew e Viner, 2001; OMT, 2003; Viner, 2006; Viner e Nicholls, 2006; Patterson, et al., 2006; Perry, 2006; Claro e Pereira, 2009), destacando-se os esforços da Organização Mundial do Turismo (OMT, 2003; UNWTO, 2007, 2009; UNWTO, UNEP e WMO, 2008). As consequências das alterações climáticas no turismo mundial não são visões remotas e estabelecidas para horizontes temporais de longo prazo. Bem pelo contrário, tais efeitos são rápidos e já bem visíveis em muitos destinos turísticos. De outra banda, a fileira do turismo tem a sua quota de responsabilidade nas alterações climáticas (emissões de gases de efeito estufa, aquecimento, ar condicionado, construção, etc). Pese embora a dificuldade em adiantar a dimensão exacta desta contribuição estima-se que o turismo seja responsável por cerca de $5 \%$ das emissões globais de dióxido de carbono (UNEP e WMO, 2008; UNWTO, 2010c).

O turismo balnear tem sido identificado como um dos mercados mais vulneráveis às alterações climáticas. Embora se reconheçam alguns efeitos positivos para o turismo balnear relacionados com o alongamento da estação estival, também o mercado de sol, praia e mar - tal como o turismo de neve constitui, cada vez mais, um segmento que está a derreter - se encontra severamente ameaçado por determinantes climáticas decorrentes do aquecimento global.

A vulnerabilidade do destino turístico Portugal às alterações climáticas é bastante acentuada na medida em que, de acordo com várias investigações (Santos et al., 2002, 2006), os impactes mais negativos das alterações climáticas serão registados na Europa do Sul, pelo que Portugal será severamente afectado. Para a bacia alargada do Mediterrâneo e, portanto, para Portugal, arrolam-se impactes negativos resultantes da elevação continuada da temperatura média global da baixa atmosfera ou troposfera, da desertificação, da escas- 
sez de água e acréscimo do stress hídrico, da tendência para o aumento da frequência e intensidade de ocorrências climáticas e meteorológicas extremas (vagas de calor, secura e precipitação intensa em períodos curtos), da propagação de doenças habitualmente restritas a climas tropicais, do aumento da incidência do cancro de pele, do incremento do risco de incêndio, da proliferação frequente de medusas e algas, alterações nas biodiversidades terrestre e marinha, bem como do risco acrescido de erosão costeira e de inundação das áreas costeiras a cotas mais baixas devido à subida do nível médio do mar (Santos et al., 2002, 2006; UNWTO, UNEP e WMO, 2008; UNWTO, 2009; Claro e Pereira, 2009).

Claro e Pereira (2009: vii) concitam a nossa atenção para a moderada e elevada vulnerabilidade da região algarvia às alterações climáticas, a qual ostenta um leque expressivo de riscos naturais - risco de incêndio florestal, risco sísmico, risco de maremoto, risco de inundação, risco de derrocada de falésias (erosão do litoral), risco de movimento de massas, risco de desertificação (solo, floresta, água e clima) - com influência na actividade turística. As alterações climáticas "poderão constituir uma ameaça significativa para a saúde pública e poderão pôr em risco o desenvolvimento turístico perspectivado para a região, dado que 0 Algarve é uma das regiões do país que apresenta alguma vulnerabilidade em termos de saúde". Citando, ainda, o trabalho destas Autoras (Claro e Pereira, 2009), no qual se investigam as possíveis consequências das alterações climáticas no conforto turístico, através do cálculo do índice climático turístico - que integra dimensões do clima referentes à temperatura, humidade, horas de sol, chuva e vento - do destino turístico mediterrânico, estimam mudanças de monta na atractividade do destino Portugal. 0 cenário global aponta no sentido de que, até cerca de 2020, o Mediterrâneo, e por consequência Portugal, percam o seu estatuto de regiões com condições muito boas ou excelentes no Verão, para passarem a ser regiões com condições aceitáveis ou marginais no Verão nos anos 2050 e 2080. A Europa do Norte, por sua vez, passará a deter excelentes condições no Verão.

Sob a perspectiva dos impactes no turismo das alterações climáticas, não podemos deixar de assinalar as pressões movidas pela erosão costeira, a qual afecta vastas zonas costeiras de Portugal e do mundo, instigada pela subida do nível do mar. Embora alguns dos factores responsáveis pela erosão costeira possam ser considerados naturais, a maior parte é consequência directa e/ou indirecta da acção humana, sendo os principais determinantes a diminuição da quantidade de sedimentos fornecidos ao litoral, a degradação antropogénica das estruturas naturais, as obras pesadas de engenharia costeira e a elevação do nível médio do mar (Dias et al., 1994). Ora, estes processos de erosão costeira têm sido acompanhados pelo acréscimo exponencial da ocupação permanente e consequente intensificação da urbanização nas zonas costeiras, processos incompatíveis e que se reforçam mutuamente (Dias et al., 1994).

Os resultados obtidos através do projecto SIAM II - Alterações Climáticas em Portugal. Cenários, Impactos e Medidas de Adaptação apontam para que $67 \%$ da costa portuguesa esteja em risco de erosão durante as próximas décadas e projectam um aumento de $15 \%$ a $25 \%$ na taxa média de erosão durante o século XXI (Santos et al., 2006). São muitas as estâncias balneares em risco, obrigando à afectação de avultadíssimos investimentos em aç̧ões correctivas de erosão e defesa costeira através da alimentação artificial de praias, da transposição de barras, da construção de molhes, esporões, paredões e outras estruturas de engenharia pesada. Para Freitas (2007), muitos destes esforços mais não são do que tentativas, infrutíferas, para tentar fixar um sistema natural que se caracteriza pela sua dinâmica. Neste cenário de erosão costeira e consequente recuo da linha de costa e num País com uma extensa frente marítima a cotas baixas, são muitas as praias que, em Portugal, se arriscam a desaparecer do mapa. No âmbito da Agenda Cascais 21, o Plano Estratégico de Cascais 
face às alterações climáticas - sector zonas costeiras refere que "considerando os cenários de subida do NMM (nível médio do mar) mais prováveis, verifica-se que a generalidade das praias do concelho de Cascais teria fortes probabilidades de desaparecer" (Taborda et al., 2010: 38), praias que são dos mais importantes recursos turísticos do concelho.

Daqui resulta que falar, hoje em dia, em praias artificiais, do mesmo modo que falamos em Alpes artificiais, nada tem de extraordinário. Ainda este ano, a Agência Lusa (14 de Junho de 2010), tendo como fonte a Administração Regional Hidrográfica (ARH) do Algarve , noticiava que estava a decorrer o maior enchimento de areia artificial de sempre "em seis praias no concelho de Loulé - Forte Novo, Almargem, Loulé Velho, Vale do Lobo, Dunas Douradas e Vale do Garrão -, numa operação que visa depositar 1,25 milhões de metros cúbicos de areia para travar a erosão costeira (...), adiantando que o investimento é de 6 milhões de euros (...). A ARH estima que com o actual enchimento artificial ao longo dos 20 quilómetros de costa marítima se consiga atrasar em cerca de 10 anos a erosão costeira naquelas seis praias, justificando que ao aumentar o areal, o natural ciclo das marés fica mais longe das dunas e arribas". Com efeito, no ano 2010, estas e outras das mais famosas praias de Portugal (Cortegaça, Esmoriz, Costa Nova, Vagueira, Furadouro, Praia da Vieira, São Pedro de Moel, Foz do Arelho, Areia Branca (Lourinhã), Samouqueira (Porto Covo) e Vasco da Gama (Sines) são algumas das mais vulneráveis) foram salvas da sentença de morte porque, de acordo com o Instituto Nacional da Água (INAG, citado por Coentrão, 2010), e em resultado da eficácia das intervenções de reposição artificial do areal e de estabilização das arribas que se têm realizado (tome-se como exemplo a Costa de Caparica), será efectuado um investimento global em acções de requalificação e defesa costeira de cerca de 100 milhões de euros, dotação integrada no Plano de Acção para o Litoral 2007-2013.

Face a estes problemas e confrontado com um contexto adverso resultante da actual crise económica global, o turismo em Portugal depara-se com novos desafios que obrigam a repensar os seus modelos de ordenamento turístico.

\subsection{Novos turismos, outros litorais: um mar de oportunidades?}

"Receio que estejamos estragando o Algarve com a pressa de dotá-lo de certo número de quartos, considerado necessário ao desenvolvimento do turismo (...) mas o turismo há-de passar e o Algarve fica. E se o deformarmos por causa do turismo nunca mais o recomporemos" (Oliveira Salazar, num despacho datado de 1965, citado por Pina, 1987: 225).

"O sector (turismo) apresenta desequilíbrios e estrangulamentos que podem, a curto prazo, comprometer o seu desejável desenvolvimento (...) a actividade turística portuguesa tem evoluído mais em termos de espontaneidade e ao sabor das perspectivas individuais do que em obediência a estratégias definidas em função de objectivos claros e conducentes à obtenção de um crescimento equilibrado (...) nunca se explicitou o papel que (o turismo) deve desempenhar no modelo de desenvolvimento da sociedade portuguesa e ainda está longe de ser uma actividade inserida no espírito e nas preocupações dos governantes e na generalidade da administração pública" (Plano Nacional de Turismo 1986/89, SET, 1984: 5)

“P: Que representa o Algarve hoje para si?

R: Uma certa desilusão do ponto de vista do ordenamento do território. Como cidadão, olhando a partir do lugar onde construí a minha casa actual no Algarve, em 1978, sou obrigado a constatar a confusão, a falta de qualidade, o desordenamento... Mas deixe que lhe diga que isso tem muito a ver com certos aspectos negativos do poder autárqui- 


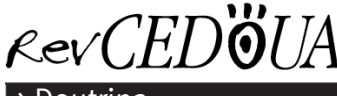 \\ Doutrina}

co que, durante muitos anos, os governos da República tiveram pejo de enfrentar (...) incluindo os meus. (...) Dito isto, tenho muitas saudades do velho Algarve". (Entrevista concedida por Cavaco Silva, enquanto primeiro-ministro, ao Público de 28/03/1995)

“A definição de uma estratégia nacional para o turismo era algo há muito ambicionado (...). Pela primeira vez existe uma clara noção das necessidades e prioridades da actividade e da estratégia para atingir o seu crescimento. (...) Outra prioridade do Governo é o correcto planeamento do uso turístico do território, contribuindo para uma utilização sustentável dos recursos turísticos, mas promovendo a redução das assimetrias regionais. Os novos pólos turísticos são disto um exemplo. A aposta numa oferta turística de interior terá, estou certo, ganhos claros para o desenvolvimento das regiões. (...) Estou certo que a actividade turística poderá ser mais utilizada para fixar as populações do interior, permitindo a formação de riqueza, a criação de emprego e servindo como um atractivo para os mais jovens. O Turismo é uma das alavancas para o desenvolvimento regional pela própria característica intangível do produto turístico e pela impossibilidade de deslocalizar a actividade. Está intrinsecamente ligado ao território, pelo que se apresenta como um dos investimentos mais eficazes no combate à desertificação das populações. Quanto à crescente litoralização, é uma das preocupações reflectidas no PENT, onde os recentes pólos de investimento turístico privilegiam as regiões interiores como o Douro, o Alqueva e a Serra da Estrela. A captação de investimento para estas regiões será um elevado contributo para o tão procurado equilíbrio do interior com o litoral". (Entrevista concedida por Bernardo Trindade, Secretário de Estado do Turismo, sobre o Plano Estratégico Nacional do Turismo 2015, à Revista Academia do Turismo, em Maio 2006)

O que vertem estas citações é que hoje, como há quarenta e cinco anos (quase meio século!), debatemo-nos com os mesmíssimos problemas, problemas tantas vezes repetidos. Os desequilíbrios regionais de desenvolvimento turístico do País persistem e agravam-se, porquanto as condições que estão na sua génese continuam a operar e engrossar os seus efeitos, não obstante o anúncio reiterado do esgotamento do padrão de implantação espacial do turismo no território nacional que vinha sendo seguido e da necessidade de estruturar um novo modelo. Não obstante, ainda, a aplicação de medidas de correcção ou, melhor, da sua não aplicação. Tal se depreende das reservas expostas, por Oliveira Salazar, pela ausência de medidas de planeamento ou das palavras de Bernardo Trindade sobre a não existência de uma política integrada de gestão do território nacional numa perspectiva de desenvolvimento turístico sustentável.

Um litoral apinhado de gente ao qual nunca se pôs ordem - ordenamento, gestão, é isto que significam -, esta é a história do intervencionismo estadual em matéria de ordenamento territorial do turismo, a qual, no essencial, pouco se desvia do percurso trilhado nas demais áreas de intervenção. Vale a pena citar Daveau (1995: 129) neste ponto: a “dissimetria crescente do País é a marca mais visível do falhanço do sempre proclamado, mas não realizado, ordenamento do território". O que está em causa é um problema de ordenamento e gestão do território, de conter as pressões turísticas sobre o território, com particular destaque para as áreas litorais.

Neste preciso ponto, não se pode deixar, todavia, de anotar quão paradoxal é esta geografia da concentração. Na esteira do pensamento de Pina (1987) e Brito (2003), muito embora seja na turistificação das zonas costeiras que encontramos a explicação para muitos dos seus problemas, é também aqui que radica o motor do seu desenvolvimento; sem o turismo, regiões como o Algarve, a Madeira ou os Açores não conseguiriam recuperar dos atrasos com que sempre se debateram.

Algumas análises discursivas salientam que a rarefeita ocupação dos litorais oceânicos afastava as questões da sua gestão do primeiro plano das preocupações da intervenção 
voluntária do Estado, pelo que a expansão do turismo balnear ocorreu com tal celeridade que a Administração foi apanhada desprevenida. Pressões partilhadas por muitas outras regiões costeiras do mundo e que impõem a necessidade da gestão turística das orlas costeiras. Um estudo da Comissão Europeia (2001: 7) sobre a inversão das tendências nas zonas costeiras europeias, identifica o mau planeamento do desenvolvimento turístico como um dos mais severos problemas susceptíveis de afectar estes territórios, enfatizando que se com "uma gestão adequada, o turismo pode transformar-se numa das principais fontes de revitalização económica das zonas costeiras (...) em muitas zonas do litoral da União, o turismo desenvolveu-se, contudo, de forma caótica e sem planeamento, estando na origem de graves problemas sociais e ambientais". Exercício de gestão difícil face ao peso económico do turismo, à crescente pressão imobiliária, às questões de sub e sobre-dimensionamento das infra-estruturas decorrentes da forte sazonalidade do turismo balnear e cuja complexidade é ampliada, entre outros aspectos, pela erosão costeira.

É neste quadro que a gestão integrada das zonas costeiras (GIZC) é considerada, pelos agentes turísticos, como o caminho a seguir no sentido do seu desenvolvimento turístico sustentável. Na medida em que a competitividade em turismo obriga à sustentabilidade, a grande moldura da transformação qualitativa do turismo preconizada no Plano Estratégico Nacional do Turismo (PENT 2015) é suportada por três orientações estratégicas - a estratégia de desenvolvimento económico e social, a estratégia nacional da conservação da natureza e da biodiversidade e a estratégia nacional de desenvolvimento sustentável -, cuja concretização obriga à gestão integrada do território e muito em particular à gestão integrada das zonas costeiras.

O mosaico de contrastes encontrado na avaliação da distribuição espacial da actividade turística e das pressões exercidas sobre estes padrões locativos no sentido da intensificação das dinâmicas concentracionárias, evidenciam marcadas vulnerabilidades, demonstrando a necessidade de questionar os princípios norteadores das estratégias de desenvolvimento que vêm sendo seguidas, bem como o futuro do turismo em Portugal. A concentração da actividade turística em áreas geográficas restritas poderá contribuir para uma diminuição do "índice de atractividade turística" de Portugal, na medida em que esta concentração gera problemas vários, os quais poderão influenciar negativamente a dinamização do turismo nas restantes regiões portuguesas, caso não se reforce a estratégia que já começou a ser adoptada no sentido da valorização das potencialidades turísticas das regiões que têm permanecido intocadas pelas dinâmicas turísticas. Aliás, as evoluções recentes das práticas turísticas demonstram uma tendência de expansão das tipologias dos espaços apropriados, tendência que procura dar resposta à progressiva segmentação da procura organizada em torno de motivações múltiplas. Tais tendências podem cristalizar-se como factores de recuperação de espaços até agora colocados à margem das dinâmicas de desenvolvimento turístico que afectam o território nacional. Por outro lado, o desenvolvimento turístico dessas regiões poderá contribuir para uma diminuição da pressão turística sobre os destinos localizados na orla costeira, destinos que apresentam níveis de utilização muito superiores à sua capacidade de carga. Caso não exista uma reorientação dos fluxos turísticos, alguns dos destinos turísticos da orla costeira de Portugal, categorizados como sendo destinos sensíveis do ponto de vista ambiental, entrarão, certamente, na fase descendente do seu ciclo de vida. Associada às diferenças regionais e locais da incidência e da captação da actividade turística encontra-se uma exagerada especialização dos produtos turísticos comercializáveis. Apesar dos objectivos da política nacional de turismo se centrarem na actuação sobre os factores críticos, designadamente, na diversificação da oferta, persiste uma excessiva predominância do turismo de sol e praia. Esta especialização, em termos de 
produtos turísticos, é causa e consequência da concentração espacial da actividade turística na faixa litoral de Portugal. Considera-se, assim, fundamental uma aposta efectiva na criação de novos produtos turísticos, baseados nas potencialidades existentes, o que contribuirá para o reforço da coesão regional através da exploração e valorização de novas áreas turísticas, como já está contemplado no PENT, entre os quais se destacam o touring, os city breaks, os congressos e incentivos, o turismo desportivo, o turismo religioso e o turismo em espaço rural.

A elevada polarização exercida pelas regiões do litoral e a consequente dependência exagerada em relação ao produto turístico sol e praia têm contribuído para uma forte sazonalidade desta actividade. Daqui resulta, também, que a estratégia em termos de oferta turística deva assentar num alisamento da sazonalidade, o mesmo é dizer, a (re)construção de produtos cuja sazonalidade apresente um padrão não homólogo ao desenhado pelos produtos turísticos tradicionais. Estas orientações têm vindo a encontrar eco em algumas estratégias definidas por actores públicos com responsabilidades neste âmbito. Em particular, refira-se o PENT que evidencia a aposta em produtos turísticos alternativos ao turismo de sol e praia e na captação de novos mercados. Sendo certo que estas medidas poderão promover a desconcentração temporal da procura turística, importa ressalvar que a sazonalidade constitui um factor inerente ao sector e com o qual este terá de aprender a viver.

E mesmo no tocante aos destinos costeiros, sabendo que o sol, praia e mar permanecem a principal motivação, o que o PENT propõe para o litoral português é a articulação de um conjunto de medidas sustentadas não apenas na requalificação do produto sol e praia tradicional mas no desenvolvimento dos seguintes produtos (Turismo de Portugal, 2007):

- turismo náutico: Portugal possui potencial para desenvolver este produto - praias de qualidade e uma vasta costa - mas as infra-estruturas do país para a sua prática são ainda desadequadas ${ }^{16}$;

- turismo residencial e resorts integrados: através da criação de resorts integrados com ofertas associadas (ex., golfe e spa)

- golfe: para além do Algarve e de Lisboa, o Litoral Alentejano e o Oeste são regiões de investimento prioritário;

- o turismo de congressos: este produto tem uma sazonalidade reduzida e complementar ao Sol e Mar, daí que seja essencial para o alisamento da sazonalidade;

- turismo de natureza: representava, em 2006, 6\% das motivações primárias dos turistas que visitam Portugal e as regiões onde este produto é mais importante são os Açores (36\%) e a Madeira (20\%).

Conclui-se, assim, que urge implementar um novo paradigma de gestão estratégica que possibilite um desenvolvimento sustentável do sector, que crie e recrie uma nova geografia do turismo em Portugal, menos litoralizada e menos polarizada metropolitanamente.

E refira-se que esta ruptura não é sinónimo de substituição do velho pelo novo turismo. Para nós, na esteira de muitos outros (Sharpley, 1994; Deprest, 1997; Wang, 2000; Agarwal et al., 2000; Shaw e Williams, 2004; Cavaco, 2006), esta ruptura, inscrita nos processos de pósmodernização do turismo, não se subsume à dicotomia entre o velho e o novo turismo e à passagem daquele a este - é, outrossim e em simultâneo, o velho e o novo. Numa análise das

\footnotetext{
${ }^{16}$ "Por exemplo, o número de marinas certificadas com a bandeira azul por cada $1000 \mathrm{~km}$ de costa marítima e rios é apenas $1 / 3$ do verificado em Espanha. No que diz respeito aos portos de cruzeiros, Lisboa representa 0 6응 porto ibérico, com $5,2 \%$ de quota de passageiros, apresentando no entanto um dos melhores crescimentos a nível europeu. De destacar ainda a importância dos portos da Madeira - Funchal e Porto Santo - que representam mais de metade dos passageiros em trânsito em Portugal. Destaque também para os portos do Funchal e de Lisboa que representam, em conjunto, um volume anual de cerca de 400.000 passageiros, valores superiores aos registados por exemplo pelo porto de Nova lorque" (Turismo de Portugal, 2007: 69).
} 
condições organizativas e estruturais da fileira turística, Agarwal et al. (2000: 250) rejeitam uma linha de análise linear e sequencial de formas de produção pré-fordista para fordista e destas para neo-fordistas, para defenderem a coexistência das três formas de acumulação num dado momento e localização, numa combinação e mútua interdependência que, longe de ser uma contradição, representa a resposta lógica às condições de produção. Constituiria uma miopia grave da investigação em turismo fazer corresponder a história dos lugares turísticos a uma sucessão de modas que se substituem: "as modas sucedem-se mas não se apagam necessariamente umas às outras: coexistem num mesmo lugar e induzem a invenção de novos lugares turísticos, mesmo de lugares criados especificamente para o turismo, que se alimentam de uma procura e portanto de uma atracção também ela criada de novo; por vezes retornam aos mesmos lugares" (Cavaco, 2006: 302). Estamos perante um entendimento em que, mais do que acentuar, em exclusivo, a profundidade das linhas de fractura operadas, se sustenta, não propriamente - é claro! - a prevalência dos fios de continuidade, mas a intensificação de certos traços, novos ou que sob nova roupagem, longe de substituir passam a coexistir com as velhas formas de turismo, o que permite que se fale em territorialidades turísticas plurais.

Numa imagem compósita e de desmultiplicação, uma das propostas que identificamos como sendo, em nosso entender, a mais promissora nos futuros processos de turistificação do território nacional - ou seja, no conjunto de processos e mecanismos que fazem com que os espaços sejam objecto de utilização para fins turísticos, numa transformação material e simbólica em espaços de consumo turístico-é a adiantada por Lopes (2005) sobre a necessidade de Portugal apostar num modelo de desenvolvimento que invista mais e melhor no macrocluster turismo-mar.

Acrescente-se que, quanto às principais tendências evolutivas da procura de turismo balnear, não se pode ignorar que longe vão os tempos de longas estadas na praia ao sol. Mesmo as tradicionais férias anuais em família, as quais não obstante a crescente fragmentação das práticas turísticas continuará a dominar o mercado de férias, perderão a sua vinculação a uma só motivação - tradicionais férias de praia na costa portuguesa - para passarem a ser uma combinação de práticas turísticas em zonas costeiras, associadas a interesses múltiplos. Argumentação alimentada pela verificação de que as práticas turísticas associadas a motivos de lazer são dominadas, no mundo ocidental, por consumidores cada vez mais pobres em tempo e que se envolvem, num zapping ininterrupto, no maior número possível de actividades de forma a maximizar as suas preciosas experiências de lazer. A competitividade dos destinos costeiros nacionais passa pela adaptação a este intensivo cocktail de motivações e densidade de actividades, em que uma procura cada vez mais experiente e exigente demanda produtos e serviços turísticos que lhes permita uma estada que combine múltiplas actividades.

Em suma, não será necessário um forte esforço analítico para nos darmos conta que, na ausência de medidas de gestão integrada dos destinos turísticos costeiros em Portugal nos arriscamos a perder o litoral e devolvê-lo à categoria de território do vazio.

Paula Alexandra Malta Assistente da Universidade de Aveiro, Departamento de Economia, Gestão e Engenharia Industrial, GOVCOPP

Celeste Eusébio

Professora Auxiliar da Universidade de Aveiro, Departamento de Economia, Gestão e Engenharia Industrial, GOVCOPP

Carlos Costa

Professor Associado com Agregação da Universidade de Aveiro, Departamento de Economia, Gestão e Engenharia Industrial, GOVCOPP 


\section{$\operatorname{RerCEDöUA~}$

\section{Referências bibliográficas}

ABEL COENTRÃO, ABEL (2010) "Vamos ter praias no Verão, mas só com muita reposição de areia". Público 25.04.2010

AGARWAL, S. et al. (1990) “The geography of tourism production: uneven disciplinary development?" Tourism Geographies, 2 (3), pp. 241-263.

AGÊNCIA LUSA (14 de Junho de 2010), on-line: http://www.regiao-sul.pt/noticia.php?refnoticia=106598

AGNEW, M.; VINER, D. (2001) "Potential impact of climate change on international tourism". Tourism and Hospitality Research, 3, pp. 37-60.

BECK, U. et al. (2003) "The theory of reflexive modernization. Problematic, hypotheses and research programme". Theory, Culture \& Society, 20 (2), pp. 1-33.

BECK, ULRICH (2000) Risk Society: Towards a New Modernity. Sage, Londres.

BELL; C.; LYALL, J. (2002) “Paradigmatic controversies, contradictions and emerging confluences". In S. Coleman e M. Crang (Eds.) Tourism between place and performance. Berghahn Books, New York, pp. 21-37.

BRITO, RAQUEL (1994) Portugal, perfil geográfico. Editorial Estampa, Lisboa.

BRITO, SÉRGIO (2003) Notas sobre a evolução do viajar e a formação do turismo. Medialivros, Lisboa.

CASIMIRO, E. et al. (2010) Plano Estratégico de Cascais face às alterações climáticas - sector turismo. Câmara Municipal de Cascais, on-line: http://www.siam.fc.ul.pt/PECAC/pdf/turismo.pdf

CAVACO, CARMINDA (1998) “Turismo(s) de ontem e de amanhã”. Economia e Prospectiva, I (4), pp. 61-78.

CAVACO, CARMINDA (2006) “Práticas e lugares de turismo”. In M. Fonseca (Coord.) Desenvolvimento e território: espaços rurais e pós-agrícolas e novos lugares de turismo e lazer. Centro de Estudos Geográficos da Universidade de Lisboa, Lisboa, pp. 299-362.

CE - Comissão Europeia (1998) Facts and figures on the European on holidays 1997-1998. Inquérito Eurobarómetro.

CE - Comissão Europeia (1999) Pour un tourisme côtier de qualité: la gestion intégrée de la qualité (GIO) des destinations touristiques côtières. Comissão Europeia, Direcção Geral das Empresas e da Indústria. Serviço das Publicações Oficiais das Comunidades Europeias, Luxemburgo.

CE - Comissão Europeia (2001) A União Europeia e as Zonas Costeiras Inverter as tendências nas zonas costeiras europeias. Serviço das Publicações Oficiais das Comunidades Europeias, Luxemburgo.

CLARO, M.; PEREIRA, M. (2009) Alterações Climáticas e Turismo - Uma Questão em Aberto. Departamento de Prospectiva e Planeamento e Relações Internacionais, Lisboa.

COCHRANE, A.; PAIN, K. (2000) "A globalizing society”. In D. Held (Eds.) A globalizing world? Culture, economics and politics. Routledge, London.

CORBIN, ALAIN (1989) O território do vazio - a praia e o imaginário ocidental. Companhia das Letras, São Paulo.

CRAVIDÃO, FERNANDA (2006) “Turismo e cultura: dos itinerários ao lugar dos lugares”. In M. Fonseca (Coord.) Desenvolvimento e território: espaços rurais e pós-agrícolas e novos lugares de turismo e lazer. Centro de Estudos Geográficos da Universidade de Lisboa, Lisboa, pp. 269-278.

DAVIDSON, T. (1994) "What are travel and tourism: are they really an industry?". In W. Theobald (Eds.), Global Tourism. The next decade. Butterworth-Heinemann, Ltd., Oxford, pp. 20-39.

DELUMEAU, JEAN (1978) La peur en Occident (XIV-XVIII siécles). Une cité assiégée, Paris, Fayard. 


\section{$\operatorname{RerCEDöUA~}$

DEPREST, FLORENCE (1997) Enquête sur le tourisme de masse. L'écologie face au territoire. Belin, Paris.

DEWAILLY, J.-M.; FLAMENT, E. (1993) Géographie du tourisme et des loisirs. Dossiers des images économiques du Monde, SEDES, Paris.

DGT (1998) "Linhas orientadoras para a política de turismo em Portugal”. Suplemento especial da Revista do Instituto Nacional de Formação Turística.

DGT (2002) Turismo em Portugal. Política, Estratégia e Instrumentos de Intervenção, DGT, Lisboa.

DIAS, J. ALVEIRINHO (2005) "Evolução da zona costeira portuguesa: forçamentos antrópicos e naturais”. Revista Encontros Científicos - Turismo, Gestão, Fiscalidade, 1, pp. 7-27.

EUSÉBIO, C.; MALTA, P. (2003) "Da avaliação da distribuição regional do turismo em Portugal às implicações no seu processo de desenvolvimento". Nova Economia e Desenvolvimento Regional: Actas do IX Encontro Nacional da APDR, Volume I, pp. 613-631.

EUSÉBIO, CELESTE (2006) Avaliação do impacte económico do turismo a nível regional O caso da Região Centro de Portugal. Departamento de Economia, Gestão e Engenharia Industrial da Universidade de Aveiro. Dissertação de doutoramento em Turismo.

FERREIRA, MARIA (1999) "O litoral português: contributos para uma "geografia das regiões litorais". Inforgeo, 6, pp. 57-66.

FREITAS, JOANA (2007) “O litoral português, percepções e transformações na época contemporânea: de espaço natural a território humanizado”. Revista de Gestão Costeira Integrada, 7(2):105-115.

HENRIQUES, EDUARDO (1993) “Do turismo urbano: Lisboa no contexto do espaço turístico português". Inforgeo, 6, Lisboa, pp. 55-70.

HIGGINS-DESBIOLLES, F. (2006) “More than an 'industry': the forgotten power of tourism as a social force". Tourism Management, 27, pp. 1192-1208.

HOUSTON, JAMES (1996) “International tourism and US beaches”. Shore and Beach.

ICEP, (2002) Estudos Turísticos: Representatividade de produtos turísticos no Turismo Nacional, ICEP, CD-ROM

INE (1971) Estatísticas do Turismo - 1970. INE, Lisboa.

INE (2008) Estatísticas do Turismo - 2007. INE, Lisboa.

INE (2009a) Conta Satélite do Turismo 2007-2009, INE, Lisboa.

INE (2009b) Estatísticas do Turismo - 2008. INE, I.P., Lisboa.

INE (2009c) Anuário Estatístico da Região Centro - 2008, INE, Lisboa.

INE (2009d) Anuário Estatístico da Região de Lisboa - 2008, INE, Lisboa.

INE (2009e) Anuário Estatístico da Região do Alentejo - 2008, INE, Lisboa.

INE (2009f) Anuário Estatístico da Região do Algarve - 2008, INE, Lisboa.

INE (2009g) Anuário Estatístico da Região Norte - 2008, INE, Lisboa.

INE (2010a) Estatísticas do Turismo - 2009. INE, Lisboa.

INE (2010b) Anuário Estatístico da Região Autónoma da Madeira - 2008, INE, Lisboa.

INE (2010c) Anuário Estatístico da Região Autónoma dos Açores - 2008, INE, Lisboa. 


\section{RerCEDőUA \\ > Doutrina}

LEIPER, NEIL (1979) "The framework of tourism. Towards a definition of tourism, tourist and the tourist industry". Annals of Tourism Research, 6 (4), pp. 390-407.

LOPES, ÊRNANI (2005) Reinventando o turismo em Portugal. Confederação do Turismo Português, Lisboa.

MACHADO, HELENA (1996) A construção social da praia. Ideal, Guimarães.

MALTA, PAULA (1996) Turismo, espaços do turismo e intervenção do estado em Portugal. Dissertação de Mestrado em Geografia, Faculdade de Letras da Universidade de Coimbra.

MAOTDR - Ministério do Ambiente, do Ordenamento do Território e do Desenvolvimento Regional (2007) Bases para a estratégia de gestão integrada da zona costeira nacional, MAOTDR, Lisboa.

MARTIN, W.; MASON, S. (1987) "Social trends and tourism futures". Tourism Management, June, pp. 112-114.

MCT - Ministério do Comércio e Turismo (1991), Livro Branco do Turismo. MCT, Lisboa.

MOLINA, A. (2003) O pós-turismo. Aleph, São Paulo.

MUNT, IANT (1994) "The other postmodern tourist: culture, travel and the new middle classes". Theory, Culture \& Society, 11, pp. 101-124.

OMT - Organization Mundial del Turismo (1990) Anuário de Estadísticas del Turismo, OMT, Madrid, ed. 43 , vol. I.

OMT - Organization Mundial del Turismo (1994) Anuário de Estadísticas del Turismo, OMT, Madrid, ed. 46 , vol. I.

OMT - Organization Mundial del Turismo (1995) Concepts, définitions et classifications des statistiques du tourisme, OMT, Madrid.

OMT - Organization Mundial del Turismo (2003) Climate Change and Tourism. Proceedings of the 1st International Conference on climate change and Tourism. OMT, Madrid.

ORTIGÃO, RAMALHO (1876) As praias de Portugal: guia do banhista e do viajante. Livraria Universal, Porto.

PABLO, PEDRO (2010) Encerramento do espaço aéreo europeu - União Europeia deve ajudar a evitar consequências económicas, online.

PATTERSON, T. et al. (2006) "Tourism and climate change: two-way street, or vicious/virtuous circle?" Journal of Sustainable Tourism, 14 (4), pp. 339-348.

PERRY, ALLEN (2006) "Will predicted climate change compromise the sustainability of Mediterranean tourism?" Journal of Sustainable Tourism, 14 (4), pp. 367-375.

PINA, PAULO (1987) A Portugal. O turismo no século XX. Ludicus, Lisboa.

RAMOS, ISABEL (2009) “Viagem pelas praias de há cem anos”. Correio da Manhã. 5 de Julho.

RIBEIRO, O.; LAUTENSACH, H. (1987) Geografia de Portugal. A posição geográfica e o território. Livraria Sá da Costa Editora, Lisboa.

RIBEIRO, ORLANDO (1987) Portugal, o Mediterrâneo e o Atlântico. Edições João Sá da Costa, Lisboa.

SANTOS, F. et al. (2002) Climate Change in Portugal. Scenarios, Impacts and Adaptation Measures - SIAM Project. Gradiva, Lisboa.

SANTOS, F. et al. (2006) Alterações Climáticas em Portugal. Cenários, Impactos e Medidas de Adaptação - Projecto SIAM II. Gradiva, Lisboa. 


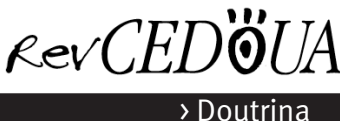

SET - Secretaria de Estado do Turismo (1984) Plano Nacional de Turismo 1986/89. SET, Lisboa.

SHARPLEY, R. (1994) Tourism, tourists and society. Huntingdon, ELM Publications.

SHAW, G.; WILLIAMS, A. (2004) Tourism and Tourism Spaces. Sage, London.

SIRGADO, JOSÉ (1993) "Turismo nas regiões portuguesas: contributo para a modelação de um cenário de desenvolvimento e inovação para o final do século”. Inforgeo, 6, pp. 21-36.

TABORDA, R. et al. (2010) Plano Estratégico de Cascais face às alterações climáticas - sector zonas costeiras. Câmara Municipal de Cascais, on-line: http://www.siam.fc.ul.pt/PECAC/pdf/zonas-costeiras.pdf

TELLES, SILVA (1932) “A individualidade geográfica de Portugal no conjunto da Península Ibérica”. Boletim da Sociedade de Geografia de Lisboa.

TURISMO DE PORTUGAL (2007) Plano Estratégico Nacional do Turismo: para o Desenvolvimento do Turismo em Portugal, Turismo de Portugal: Lisboa.

TURISMO DE PORTUGAL (2008) Conta Satélite do Turismo: actividade económica 2000-2007. Direcção de Estudos e Planeamento Estratégico/ Departamento de Informação Estatística.

TURISMO DE PORTUGAL (2009a) Anuário das Estatísticas do Turismo - 2008. Direcção de Estudos e Planeamento Estratégico/ Departamento de Informação Estatística.

TURISMO DE PORTUGAL (2009b) O turismo na economia. Indicadores de actividade turística e económica em Portugal - 2008. Direcção de Estudos e Planeamento Estratégico/ Departamento de Informação Estatística.

TURNER, L.; ASH, J. (1975) The golden hordes. Constable and Co. Ltd Editors, London.

UCPT - Unidade de Coordenação do Plano Tecnológico (2005) Plano Tecnológico. UCPT, Lisboa.

UNWTO - United Nations World Tourism Organization (2007) From Davos to Bali: A Tourism Contribution to the Challenge of Climate Change.

UNWTO - United Nations World Tourism Organization (2008) Tourism Highlights - 2008 Edition, Madrid: WTO, on-line.

UNWTO - United Nations World Tourism Organization (2009) Rapport sur le Séminaire Tourisme côtier en Méditerranée: Adaptation au changement climatique. OMT, Madrid.

UNWTO - United Nations World Tourism Organization (2010a) Panorama del turismo internacional 2009. OMT, Madrid.

UNWTO - United Nations World Tourism Organization (2010b) Press Release. WTO, on-line: http:// www.unwto.org/media/news/en/press.php?op $=1 \&$ subop $=1$

UNWTO - United Nations World Tourism Organization (2010c) Climate Change and Tourism. WTO, on-line: http://www.unwto.org/climate/faq/en/faq.php?op=4

UNWTO, UNEP e WMO (2008) Climate Change and Tourism: Responding to Global Challenges, UNWTO, Madrid, and UNEP, Paris. Online:http://www.unwto.org/sustainable/doc/climate2008.pdf

VINER, D. (2006) “Tourism and its interactions with climate change”. Journal of Sustainable Tourism, 14 (4), pp. 317-322.

VINER, D.; NICHOLLS, S. (2006) "Climate change and its implications for international tourism". In D. Buhalis e C. Costa (Eds.) Tourism management dynamics. Trends, management and tools. Elsevier Butterworth-Heinemann, Oxford, pp. 39-50.

Wang, Ning (2000) Tourism and modernity. A sociological analysis. Elsevier Science, Oxford.

WTTC - World Travel and Tourism Council (2010) Tourism Impact Data and Forecasts, on-line. 